\title{
Neurological manifestations of coronavirus infections, before and after COVID-19: a review of animal studies
}

\author{
Atefeh Bakhtazad ${ }^{1} \cdot$ Behzad Garmabi $^{2} \cdot$ Mohammad Taghi Joghataei $^{1}$
}

Received: 13 July 2020 / Revised: 15 July 2021 / Accepted: 20 August 2021 / Published online: 2 November 2021

(c) Journal of NeuroVirology, Inc. 2021

\begin{abstract}
Coronavirus disease 2019 (COVID-19) is an infectious disease caused by severe acute respiratory syndrome coronavirus 2 (SARS-CoV-2). This virus, which was first identified in December 2019 in China, has resulted in a yet ongoing viral pandemic. Coronaviridae could potentially cause several disorders in a wide range of hosts such as birds and mammals. Although infections caused by this family of viruses are predominantly limited to the respiratory tract, Betacoronaviruses are potentially able to invade the central nervous system (CNS) as well as many other organs, thereby inducing neurological damage ranging from mild to lethal in both animals and humans. Over the past two decades, three novel CoVs, SARS-CoV-1, MERS-CoV, and SARS-CoV-2, emerging from animal reservoirs have exhibited neurotropic properties causing severe and even fatal neurological diseases. The pathobiology of these neuroinvasive viruses has yet to be fully known. Both clinical features of the previous CoV epidemics (SARS-CoV-1 and MERS-CoV) and lessons from animal models used in studying neurotropic CoVs, especially SARS and MERS, constitute beneficial tools in comprehending the exact mechanisms of virus implantation and in illustrating pathogenesis and virus dissemination pathways in the CNS. Here, we review the animal research which assessed CNS infections with previous more studied neurotropic CoVs to demonstrate how experimental studies with appliable animal models can provide scientists with a roadmap in the CNS impacts of SARS-CoV-2. Indeed, animal studies can finally help us discover the underlying mechanisms of damage to the nervous system in COVID-19 patients and find novel therapeutic agents in order to reduce mortality and morbidity associated with neurological complications of SARS-CoV-2 infection.
\end{abstract}

Keywords Coronavirus $\cdot$ COVID-19 $\cdot$ SARS-CoV-2 $\cdot$ Neurology $\cdot$ CNS $\cdot$ Animal study

\section{Introduction}

Coronaviruses (CoVs) are highly prevalent animal and human pathogens with many known hosts (Felsenstein et al. 2020). Thousands of species of CoVs are currently recognized around worldwide. Up to now, seven CoVs are known as human pathogens (Ye et al. 2020). The Coronaviridae family is divided into the following two subfamilies:

Mohammad Taghi Joghataei

Joghataei.mt@iums.ac.ir

Atefeh Bakhtazad

a-bakhtazad@alumnus.tums.ac.ir

1 Cellular and Molecular Research Center (CMRC), Iran University of Medical Sciences, 1449614535 Tehran, Iran

2 School of Medicine, Shahroud University of Medical Sciences, Haft-Tir Sq, University Blv, 3614773947 Shahroud, Iran
Coronavirinae and Torovirinae (of the International 2020). Coronaviridae usually circulates among some animals such as pigs, cats, camels, and bats. It was demonstrated that sometimes this subfamily can jump to humans yet. This phenomenon is called a spillover event (Wang and Anderson 2019), which induces infections that are generally limited to mild to moderate levels of upper respiratory tract illnesses like common cold (Organization WHO 2019). However, over the past two decades, three new coronaviruses (named SARS-CoV, MERS-CoV, and SARS-CoV-2) emerging from animal reservoirs have caused severe, even fatal, diseases that affected the population of the whole world ( Wu et al. 2020a, b).

By the end of 2019, corona virus disease 2019 (COVID19) occurred in one of China's cities, Wuhan, which attracted the global attention (Organization 2020a, b, c, d, e). The rise of this $\mathrm{CoV}$, causing a severe acute respiratory syndrome, SARS-CoV-2 disease, or COVID-19, in China has led to a 
vast outbreak worldwide and then become a foremost public health matter (Huang et al. 2020). On 11 June, 2021, data from the World Health Organization (WHO) have publicized that around 175,000,000 confirmed cases have been identified up to that time, with approximately 3,770,000 deaths in 193 affected countries and territories worldwide and two international conveyances. People affected with COVID-19 have had a wide variety of symptoms ranging from mild symptoms to severe illness (Organization 2020a, b, c, d, e). Although most cases with SARS-CoV-2 infection, COVID19 (about $80 \%$ ), present mild symptoms, up to $15 \%$ of the patients might develop severe disease type and need at least ventilation support. Approximately 5\% of all these cases will progress toward a very critical illness that requires intensive care, ICU (Lippi et al. 2020).

It was recently established that besides respiratory symptoms that are almost always seen in patients with COVID19 , around $40 \%$ of the patients exhibit some neurotropic properties, which may consequently cause neurological diseases such as dizziness, confusion, languidness, convulsion, headache, impaired consciousness, seizure, paresthesia, acute cerebrovascular disorders, and neurocognitive problems (Wang et al. 2020). Furthermore, in February 2020, some medical doctors in some specific affected regions have reported that some patients diagnosed with COVID-19 in terms of their polymerase chain reaction (PCR) data have shown no characteristic respiratory symptoms of this disease such as chills, fever, and dry cough, at the time of their initial diagnosis. On the other hand, they have exhibited some neurological signs and symptoms, and these manifestations were found to be more likely to develop in severely affected patients than those who have shown a mild or moderate level of the disease (Azhideh 2020). In March 2020, physicians working in a hospital in China introduced a case of respiratory disease who presented with acute viral encephalitis (Wu et al. 2020). Besides, by applying genome sequencing, researchers established SARS-CoV-2 in the cerebrospinal fluid (CSF) (Domingues et al. 2020). Finally, based on all these gathered data, Xiang et al. in their study proposed that this new CoV can potentially cause nervous system damage (Xiang et al. 2020). Further studies conducted on neuronal tissue autopsy reports from different sites of the peripheral nervous system (PNS) as well as central nervous system (CNS) in the patients with COVID-19 have disclosed both of these nervous systems' involvement, including tissue edema, acute hemorrhagic necrotizing encephalopathy, and neurodegeneration with progressive loss of the structure or the function of neurons in dead patients (Singh et al. 2020).

Although neurological symptoms are not very common in $\mathrm{CoV}$ infections compared to respiratory symptoms, the high number of COVID-19 patients with neurological complications has explicated neurotropic properties of SARS-CoV-2 . Since the neurological disorders induced by other $\mathrm{CoV}$ s have been divided into early onset and delayed onset, so there is an urgent need to understand the correct mechanisms of the entrance of this virus into the nervous system and causing brain cell diseases both in the short term and long term. As these underlying mechanisms are not fully understood yet, so no appropriate therapeutic strategy would be discovered for each neurological complication induced by SARS-CoV-2 attack to both the central and peripheral nervous systems.

One of the fundamental ways to better understand the complex temporal relationships between such contagious organisms and whole body disorders, including the nervous system, is applying the right animal models. Accordingly, this way is almost always used to find out the myriad of hostpathogen interactions associated with infectious diseases, especially since the time that the current basis of biology has reached the molecular level.

In this review, at first, we take a look at both the $\mathrm{CoV}$ family's structure and function. In this regard, we attempt to focus on CoV's special subfamilies, which can consequently develop neurological complications in particular hosts. Finally, we emphasize the extreme emergent need of creating a well-designed animal model used to understand the SARS-CoV-2-neural system interactions, in order to find safe and efficacious strategies regarding both prevention and therapy.

\section{Coronaviruses}

Coronaviridae is a family of enveloped, positive-strand RNA viruses that can infect birds, amphibians, and mammals. This group of viruses comprises the following two subfamilies: Letovirinae and Orthocoronavirinae. Of note, nowadays, the members of the latter are also recognized as coronaviruses. Accordingly, the particles are typically decorated with large $(\sim 20 \mathrm{~nm})$, club/petal-shaped surface projections (the peplomers or spikes) that create an image suggestive of the solar virus in electron micrographs of spherical particles (Velavan and Meyer 2020). CoVs and toroviruses are the two virus genera within the virus family Coronaviridae, order Nidovirales (De Groot et al. 2011). While CoVs are well-established pathogens of both humans and animals, toroviruses are responsible for animal diarrhea (Lu et al. 2020a, b, c).

CoVs were firstly discovered in the 1930s in domesticated chickens infected by infectious bronchitis virus (IBV) by causing acute respiratory disease (Luo et al. 2014). The viruses included in this subfamily were named for their natural host and occasionally for the related organ's disease, for instance, mouse hepatitis virus (MHV), avian infectious bronchitis virus (IBV), sialodacryadenitis virus (SDAV), bovine coronavirus (BCoV), porcine hemagglutinating encephalomyelitis virus (PHEV), porcine respiratory 
coronavirus (PRCV), turkey bluecomb coronavirus (TCoV), human respiratory coronavirus ( $\mathrm{HRCoV})$, canine coronavirus $(\mathrm{CCoV})$, feline infectious peritonitis virus (FIPV), and rabbit coronavirus (RbCoV) (Fung and Liu 2021). Although many other family viruses were also discovered in following years, they have been of more significant concern to agriculture than to human beings' health. However, when severe acute respiratory syndrome (SARS) in China in 2002-2003 has emerged by infection with one of the CoVs (SARS-CoV), the international view completely changed on the pathogenicity of the Coronaviridae family (Drosten et al. 2003; Woo et al. 2009).

The CoV subfamily can further be classified into the following four genera: alpha, beta, gamma, and delta CoVs. Alphacoronavirus such as E229 and NL63, Betacoronavirus such as OC43 and HKU1, and all novel CoVs primarily infect mammals. Although Gammacoronavirus and Deltacoronavirus only infect birds initially, they can eventually infect both mammals and birds (Organization 2020a, b, c, d, e). The human coronaviruses (HCoVs) are placed in two of the above-mentioned genera: Alpha (HCoV-NL63 and HCoV-229E) and Betacoronaviruses (HCoV-OC43, HCoV-HKU1, Middle East respiratory syndrome coronavirus (MERS-CoV), severe acute respiratory syndrome coronavirus (SARS-CoV-1), and SARS-CoV-2) (Loeffelholz and Tang 2020).

Bats and birds are considered ideal natural reservoirs for the CoV gene pool. A considerable number of host bats and avian species allow this family of viruses to evolve extensively and then distribute expansively throughout all regions in the world (Wertheim et al. 2013). Moreover, it has been demonstrated that CoVs are able to affect humans as well as other species, including birds and mammals such as bats, cats, cows, dogs, pigs, and rodents, and to induce respiratory, hepatic, intestinal, and neurological pathologies (Woo et al. 2012). As mentioned earlier, three novel Betacoronaviruses, SARS-CoV-1 (Cheng et al. 2007), MERS-CoV (Chan et al. 2015a, b), and SARS-CoV-2 (Zhang and Holmes 2020), which can lead to severe human diseases, have emerged over the past 18 years (see Fig. 1).

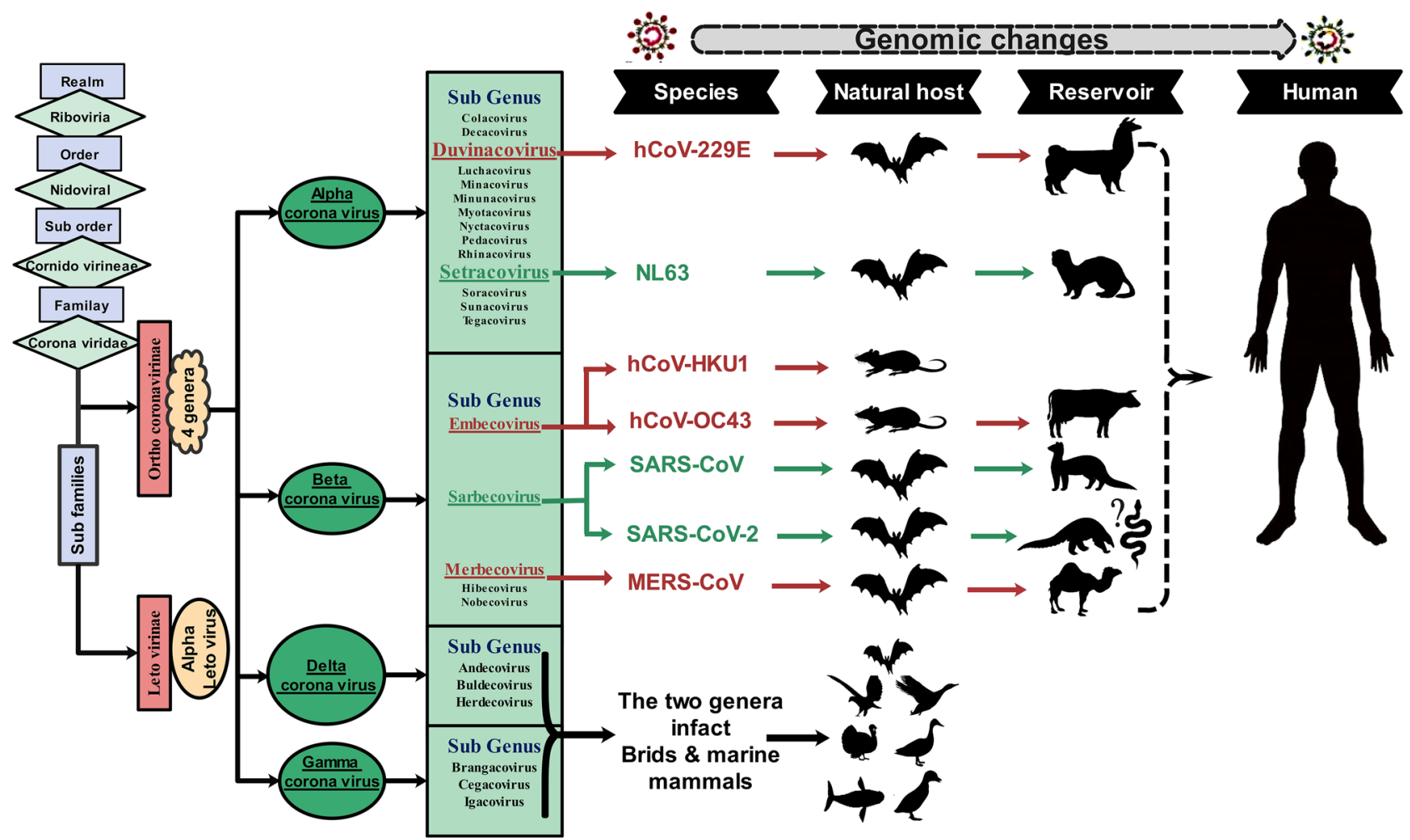

Fig. 1 Taxonomy of Coronaviridae based on the International Committee on Taxonomy of Viruses indicates species known to be pathogenic to humans. In a complicated evolutionary structure, changes in molecular virus genome empowered appearance and jumping from the first host to the intermediate host, and eventually to humans, the phenomenon called "spillover event" (Hussein et al. 2020) 


\section{Neurological complications of CoVs infections in animals}

\section{Neuro-infections with CoVs (except SARS-CoV-1, MERS-CoV, and SARS-CoV-2) in animals}

It is currently cleared that a variety of neurological diseases in humans have a viral etiology. Furthermore, the accumulated data suggested that the $\mathrm{HCoVs}$ can infect humans' CNS as well as non-human primates' CNS (Desforges et al. 2020). Accordingly, when they cross the $\mathrm{BBB}$, they can spread throughout the CNS via several routes. Some of these have been proven, and some others are not fully confirmed yet. The possible distribution pathways of CNS infection with HCoVs are as follows: (1) through the olfactory nerve to the olfactory cortex of the temporal lobe to the hippocampus to the amygdala, or hypothalamus; (2) via the serotoninergic dorsal raphe system; (3) through the hematogenous route and VirchowRobin spaces; (4) via the lymphatic system (see Fig. 2).

Therefore, to study the neurological manifestations of patients affected with CoVs, especially the novel SARSCoV-2, it is better to look at first how this genus of Coronaviridae family can affect animals' nervous systems in nonhumans' studies. Molecular analyses of different strains of CoVs and the use of mutant, recombinant, and antigenic variant viruses have made it possible to discover which genes or gene products account for neurotropism. This section reviews the effects of CoVs (except SARS-CoV-1, MERS-CoV, and SARS-CoV-2) infections on animals' nervous systems in previous experimental investigations.
As discussed earlier, several CoVs have been identified with some potential neuroinvasive properties and then classified as neurotropic CoVs.

One of the most recognized species included in this class of $\mathrm{CoV}$ is murine $\mathrm{CoV}(\mathrm{M}-\mathrm{CoV})$. This Betacoronavirus is an enveloped, positive-sense, single-stranded RNA virus that could initiate entering its host tissue cell by binding to the CEACAM1 receptor (Fehr and Perlman 2015). In addition, $\mathrm{M}-\mathrm{CoV}$ can induce a murine epidemic illness with high mortality rate, particularly among mouse laboratory colonies. Before the detection of SARS-CoV, M-CoV, as a specifically mouse hepatitis virus (MHV), had been the best-studied $\mathrm{CoV}$ under both in vivo and in vitro (Chiow et al. 2016). MHV is a collection of strains that induce the disease in several organ systems of mice and rats. Some strains of MHV, like MHV-JHM, are mainly neurotropic (Rout et al. 2020), and MHV-A59 (Lavi and Cong 2020), MHV-S (Körner et al. 2020), and MHV-3 are both hepatotropic and neurotropic (Zandifar and Zandifar 2020).

Several studies have attempted to find the correlation of inflammatory neurological diseases with coronavirus infections. In 1992, Murray et al. in their study intracerebrally inoculated two species of primates, owl and African green monkeys, either with MHV-JHM or with the putative multiple sclerosis brain coronavirus isolated SD. They established that although these viruses are able to replicate and disseminate in the CNS of these primates and then cause an acute to subacute panencephalitis and demyelination in the infected animals, the course of pathogenesis and also brain regions in which viral RNA and antigen can be detected were found to be utterly dependent on the following two
Fig. 2 Possible distribution pathways of CNS infection with HCoVs: (1) olfactory nerve to olfactory cortex of temporal lobe to hippocampus to amygdala, or to hypothalamus; (2) via serotoninergic dorsal raphe system; (3) through hematogenous route and Virchow-Robin spaces; (4) via lymphatic system. (Dissemination pathways with empirical data are designated by solid indicators, and theoretical ones are indicated by dot arrows.) This figure is modified from Cheng et al. (2020) with permission

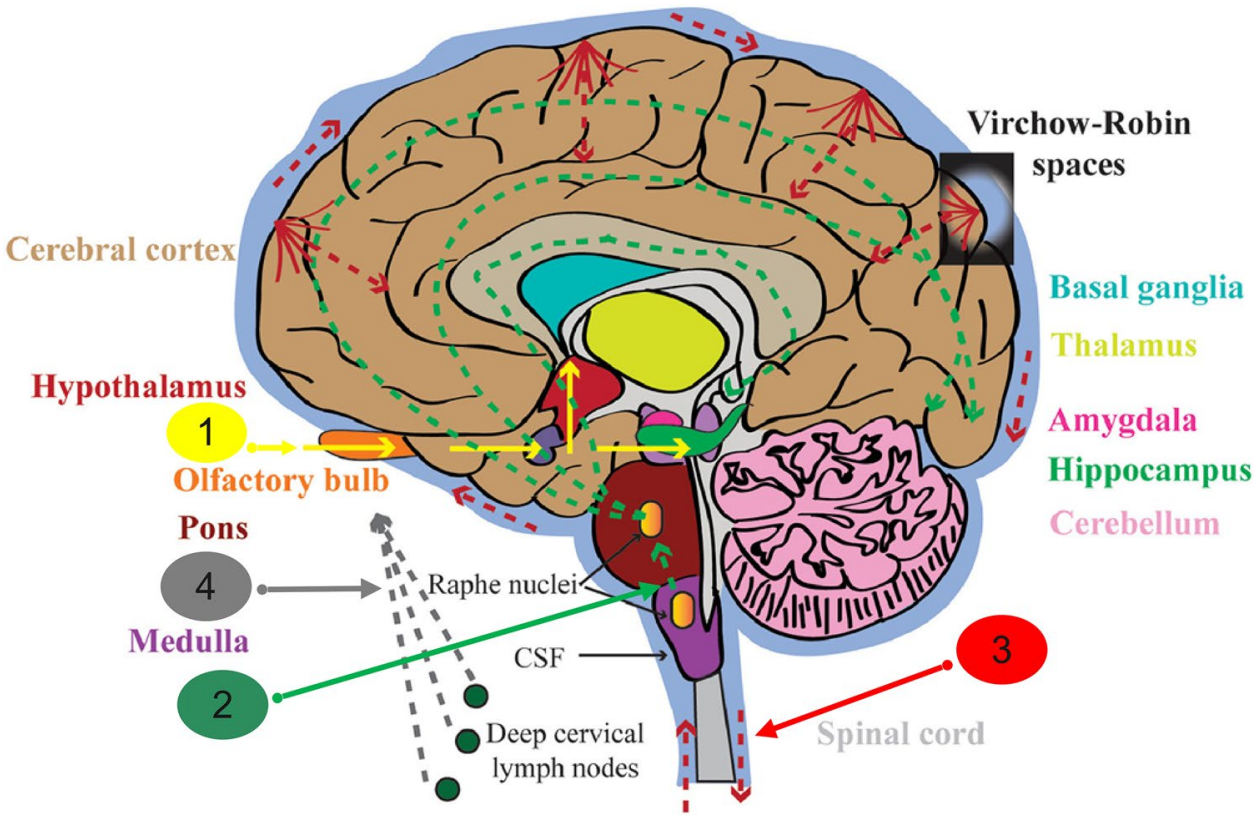


key factors: animal species and virus strain. Based on the obtained results, they suggested that infection with CoVs might induce or contribute to some human CNS diseases (Murray et al. 1992). More studies are needed to understand the possible interactions among MHV strains, animals' brains, and spinal cords identified specific prototype strains of MHV that can induce acute encephalitis and/or white matter demyelination in rodents (Matías-Guiu et al. 2020; Sarkar et al. 2020).

All the experimental animals inoculated with neurotropic strains of MHV developed a bi-phasic neurological disorder. Accordingly, in the first 2 weeks (acute phase), the animals showed acute meningoencephalitis, and subsequently, they demonstrated a subacute and/or chronic demyelinating disease induced by immune system-mediated damages to neuronal axons (Dandekar et al. 2001). Other studies also established that the acute phase's clinical symptoms in mice or rats might be ranged from asymptomatic illness (Lavi and Weiss 2012) to severe disease or even death (Herndon et al. 1975; Körner et al. 2020). By supposing that the animal can survive the acute phase of neuro-infection, it may advance into the chronic phase marked with paralytic diseases. The animal may experience the chronic demyelination phase that might be monophasic or relapsing-remitting (with fractional or ample recovery) or a steady worsening of symptoms from the start of the disease (gradually progressive) to death (Lavi and Weiss 1989). Altogether, previous animal studies supported the hypothesis that immunopathogenic response initiated with $\mathrm{CoV}$ s infections could lead to demyelinating processes either in the brain or in the spinal cord (Almaghaslah et al. 2020). Besides, the severity of the disease was found to be dependent on several factors that can be classified into the following two categories: (1) the strain, the dose, and the route of inoculation of the virus; (2) the species, the strain, and the age of the infected animal (Lavi and Weiss 2012). It was shown that neurological manifestations induced by a specific strain of $\mathrm{CoV}$ can be different in various animal species and these may also be dissimilar within diverse strains of a particular species, because different strains of species have different susceptibilities to CoV-induced demyelinating encephalitis. For example, the Lewis Rat strain shows completely different neurological symptoms and dissimilar arrangements of infiltrating lymphocyte subsets in virus-infected tissues compared to the Brown Norway Rat strain (Dörries et al. 1991). Although many studies reported a positive correlation between histopathological findings and the severity of neurological deficits, some other reports showed severe neuropathological changes caused by MHV infection, even in the absence of any neurological sign or symptom (Chakravarty and Sarma 2021) (see Fig. 3).

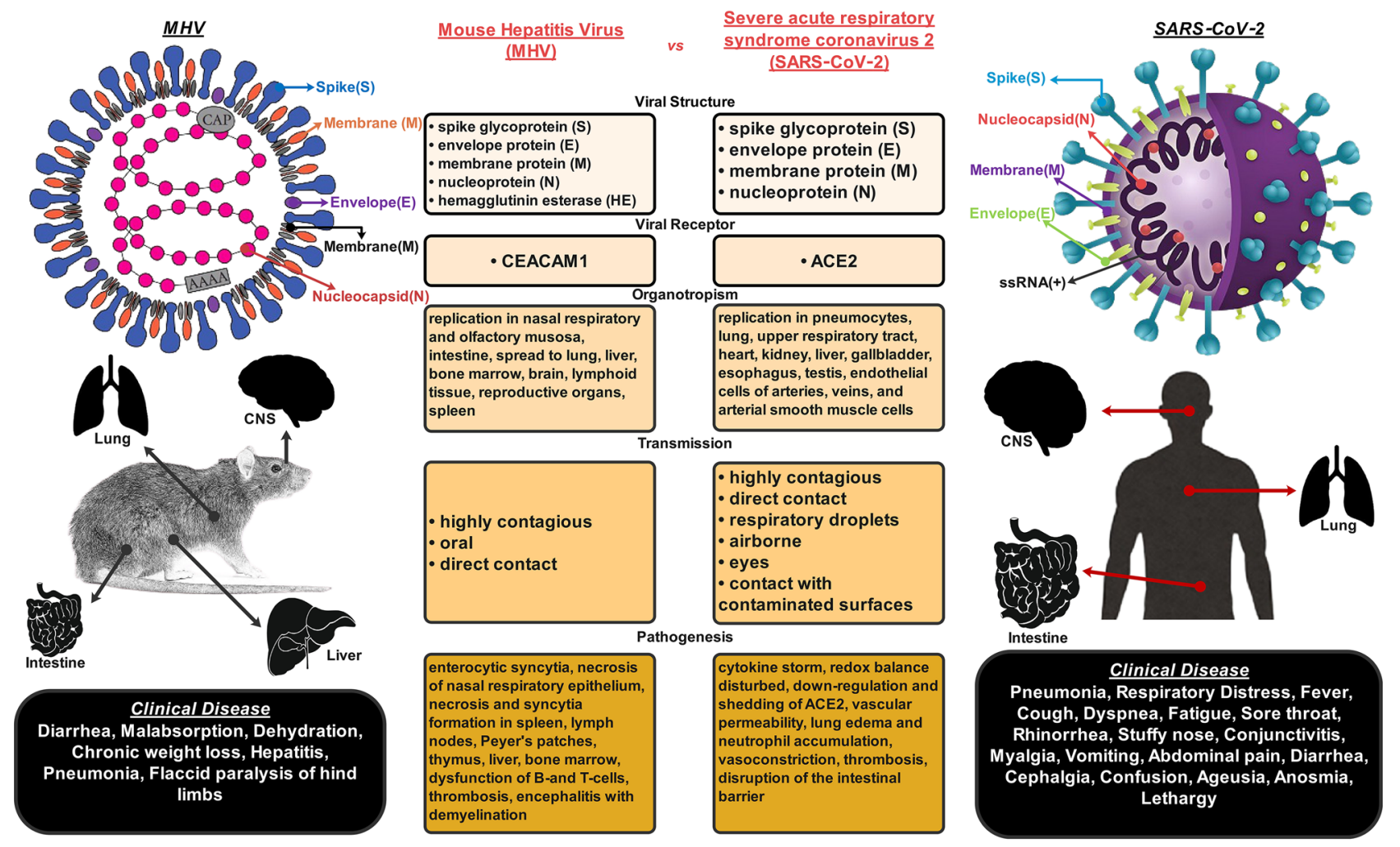

Fig. 3 Summary of the main similarities and differences between the CoV-MHV and SARS-CoV-2. This figure is modified from Körner et al. (2020) with permission and the image of SARS-CoV-2 is modified from Santos et al. (2020) with permission 
In contrast to MHV-JHM causing a lethal brain disorder, another MHV strain called MHV-A59 could induce a non-lethal CNS disease in weanling mice with the involved neurons, and surrounding glial cells as well as meninges. When a high dose of virus is administered, besides mild encephalitis, hepatitis also happens, which is able to cause death (Lavi and Weiss 2012). While intracerebral inoculation with MHV-A59 mostly involves the basal ganglia in mice (Bender and Weiss 2010), intranasal inoculation can lead to virus propagation within the olfactory pathways (see Fig. 3). Subsequently, this involves the limbic system (Lavi and Weiss 2012). The kinetics of the CoV antigen's presence in the CNS could highly mimic a physiological signal's dissemination pattern in the limbic system. Accordingly, this finding proposed an intraneuronal virus transportation system. Altogether, these results indicate that the receptor with a high affinity for the specific $\mathrm{CoV}$ might be regarded as a molecule shared by the limbic system neurons, which can probably be a neurotransmitter receptor (Bailey et al. 2017).

It was observed that MHV-3, as another MHV strain, can cause various diseases, including lethal hepatitis and neurological disorders, in laboratory mice. This outcome entirely depends on the age, on immune system status, and mainly on the host's strain. Semi-susceptible strains like C3H mice become persistently infected, manifesting largely as neurological complications such as ependymitis, encephalitis, and hydrocephalus, which are the hallmarks of neurological diseases mediated by MHV-3 infection (Tabet et al. 2018).

Adami et al. in their study indicated that the RNA of the neurotropic CoVs has persisted in the mouse brains while infectious virus could not be more detectable (Fallahi et al. 2019). For example, while $\mathrm{CoV}$ had persisted in mouse brains for only 13 days after being inoculated with a neuroattenuated variant of MHV, its RNA was detected using RTPCR by passing 42 days from infection (Tabet et al. 2018). In another study, five owl monkeys were intracerebrally inoculated with coronavirus JHM-OMP1. This virus isolate was then cultured from the brain of an animal inoculated with uncloned MHV-JHM. Thereafter, two of the monkeys developed severe encephalomyelitis. Of the remaining three healthy animals, two were intracerebrally inoculated again at 90 days post-first inoculation. Those three healthy animals were sacrificed by passing about 5 months from the first-time virus inoculation. Although Cabirac et al. in their research could not detect any infectious virus, viral RNA, and antigen in the brain tissues, all three owl monkeys had substantial inflammation in white matter as well as in several demyelinating regions in their spinal cord. In the following study done by this research team, the studied animals were firstly inoculated with JHM-OMP1 either intranasally or intravenously. After 152 days, most of them were given a second IV inoculum and sacrificed between 16 and 215 days post-infection. Viral RNA and antigen were then detected in all these animals' brains with the distribution patterns similar to neuroinflammatory regions. Furthermore, some animals developed neurological impairment with viral antigens in both their brain and spinal cord. The most exciting finding of this study was discovering remarkable loads of viral products in blood vessels. As a result, it was demonstrated that the mechanism of MHV-JHM acts in a way that it enters and then hematogenously spreads into the CNS through endothelial cells (Cabirac et al. 1994).

Several factors can affect the susceptibility of an animal to present neurological symptoms of $\mathrm{CoV}$ infection. While infection with several MHV strains in the rat can cause demyelinating encephalomyelitis induced by activated/ hyperactivated immune system, the neurological outcome of the infection induced by $\mathrm{CoV}$ is principally determined by the strain of the virus, the genetic background of the strain, and the age of the animal (Schwender et al. 1991; Decaro and Lorusso 2020). Although most CoVs do not persist for a long time in immunocompetent hosts after the infection, some CoVs like the neurotropic MHV-JHM strain may occasionally be found in the animal's nervous system even after years from inoculation. Another factor affecting an animal's ability to survive after MHV-JHM infection is the coordinated action of the $\mathrm{T}$ cell and $\mathrm{B}$ cell compartments. In a previous study, Schwender et al. established that brain tissue destruction and acute paralysis that occurred during the acute phase of JHM-induced encephalomyelitis in Lewis rats were primarily mediated by $\mathrm{T}$ cells. They mentioned that although CD4 + T lymphocytes are the cells directly dedicated to reducing the CNS viral load, only the capacity of the coordinated actions of both $\mathrm{T}$ cells and $\mathrm{B}$ cells can help in the processes of recovery and optimization of the animal's chance for survival after MHV-JHM-related infection (Bender and Weiss 2010). Fleming et al. also showed that the pathogenicity of antigenic alterations of neurotropic JHM viruses is predominantly dependent on the type of anti-E2 (as a viral glycoprotein) antibody-selected variants. Moreover, they studied two different types of monoclonal antibodies, namely J.7.2 and J.2.2., which bind to different topographically regions of the E2 viral glycoprotein. The variants chosen with the two antibodies revealed some absolutely diverse neurological diseases in mice. While the selected variants with J.7.2 were extremely poisonous and produced an acute encephalitic illness, J.2.2-selected variants mainly resulted in some clinically subacute paralytic diseases or extensive demyelinating disorders (Fleming et al. 1986).

It has been discovered that about $30 \%$ of the rats infected with MHV-JHM developed a subacute demyelinating encephalomyelitis within 3 weeks after first inoculation. As well, around $5 \%$ of the animals developed several chronic demyelinating diseases up to 8 months after their first inoculation. It has been suggested that the virus-host relationships 
may be responsible for the demyelinating process that happened after a long period post-incubation. Moreover, in the CNS and PNS, remyelinated areas have been observed in about $40 \%$ of the clinically silent animals by passing 8 months from the first inoculation (Nagashima et al. 1979; Oliveira et al. 2020). Although immunological events can determine the consequences resulted from the infection with this $\mathrm{CoV}$ in laboratory mice, these are not entirely attributed to the different immune competence stages (Pickel et al. 1981; Kumar 2020) (see Fig. 3).

According to all the above-mentioned findings, even though neurological diseases caused by murine $\mathrm{CoVs}$ are clearly dependent on the complex interactions among virus, host, and the environment (Fleming et al. 1987, Chakravarty et al. 2020), these strains of viruses have been expansively used to induce several animal models proposed for experimental neurological diseases (Martin and Nathanson 1979; Torre-Fuentes et al. 2020).

Further studies conducted on another species of Betacoronavirus, namely $\mathrm{HCoV}-\mathrm{OC} 43$, in mice, showed that while mouse nervous system can be attacked by this $\mathrm{CoV}$, some specific species of mice as well as particular types of neurons were more susceptible to this infection than others. Intracerebral inoculation of $\mathrm{HCoV}-\mathrm{OC} 43$ into $\mathrm{BALB} / \mathrm{c}$ mice caused acute encephalitis along with neuronal cell death. Additionally, viral RNA persevered in neurons up to several months post-infection, which leads to chronic motor deficit following the neurodegeneration process in susceptible animals (Jacomy et al. 2006).

Porcine hemagglutinating encephalomyelitis virus (PHEV), which was classified as a member of the genus Betacoronavirus, belonged to Coronaviridae family, is another neurotropic $\mathrm{CoV}$ that can cause CNS dysfunctions, including non-suppurative encephalitis, cerebral cortex degeneration, necrosis, and neuronophagia in suckling pigs. Additionally, PHEV infection in neurons that innervate the stomach can cause nausea and vomiting, as well as wasting syndrome (Decaro and Lorusso 2020). More studies performed on the PHEV-positive labeling of neurons in cortical areas of infected mice or dead piglets maintained this virus's ability in inducing pathogenesis in animals' nervous system (Li et al. 2016). The neural cell adhesion molecule (NCAM) has been identified as a receptor for this $\mathrm{CoV}$ action in the CNS (Gao et al. 2010).

Feline infectious peritonitis virus (FIPV) is another $\mathrm{CoV}$ causing disseminated disease in several specific systems like the nervous system. In addition, this can replicate in both neurons and glial cells of animals (Holmes 1999; Wang et al. 2018). It was established that only around $10 \%$ of all cats affected with feline infectious peritonitis (FIP) presented neurological signs and symptoms (Rohrer et al. 1993; Kline et al. 1994; Dickinson et al. 2020). Besides, they mostly showed virus-induced pyogranulomatous meningomyelitis and meningoencephalitis (Slauson and Finn 1972; Kline et al. 1994; Mariani 2020). In this regard, the most generally described neurological signs are ataxia, nystagmus, seizures, hyperaesthesia, and several cranial nerve involvements (Barnes et al. 2004; Timmann et al. 2008). However, a multifocal location is established in most FIPV infection cases, and focal neurological signs may also happen sporadically (Timmann et al. 2008; Diaz and Poma 2009). In cats with FIP who present neurological involvement symptoms, the $\mathrm{CoV}$ can be detected in the CSF only if the virus is replicated in the CSF macrophages. Because in the CNS, similar to other tissues of the body, the macrophages resemble the principal target cells. As well, FIPV uses macrophages to enter the nervous tissue cells (Foley and Leutenegger 2001; Watanabe et al. 2018).

Briefly, despite the reason that the entry route of this CoV into the CSF is unidentified yet, it seems that FIPV possibly trespasses the blood-brain barrier (BBB) cell-bound within macrophages. Therefore, real-time viral PCR could be considered a useful technique in identifying CSF FIPV, due to having excellent specificity and sensitivity for diagnosing FIP in cats, at least in those presenting neurological signs. So, RT-PCR could be used as an exciting tool for diagnosing neurological FIP (Doenges et al. 2016). Since a positive correlation exists between serum and CSF IgG, the evaluation of the anti-CoV IgG level in the CSF of infected cats with FIPV could be known as another promising clinical biomarker for detecting the involvement of the CNS in FIPV infection (Boettcher et al. 2007; Malbon et al. 2020).

\section{Neuro-infections with SARS-CoV-1, MERS-CoV, and SARS-CoV-2 in animals}

\section{Neuro-infection with SARS-CoV-1 in animals}

Severe acute respiratory syndrome (SARS) is a viral disease with zoonotic origin that surfaced during 2002-2004. SARS outbreak resulted from a highly pathogenic Betacoronavirus, called severe acute respiratory syndrome coronavirus (SARS-CoV or SARS-CoV-1), which is the first-identified strain of the SARS-CoV species. Chinese virologists traced this virus through civets' intermediary to cave-dwelling horseshoe bats in Yunnan province (Robin 2017). The outbreak of SARS has demonstrated human vulnerability to CoV epidemics (Pfefferle et al. 2011; Gomes et al. 2020). Accordingly, its symptoms are flu-like and may also include fever, sore throat, cough, muscle pain, lethargy, and other nonspecific symptoms. Moreover, SARS can ultimately cause shortness of breath and pneumonia, either direct viral pneumonia or secondary bacterial pneumonia (Organization 2003). The mortality rate of SARS disease was estimated as about 10\% (Knobler et al. 2004; Giannis et al. 2020). While comparatively fewer neurological complications have 
been observed during earlier $\mathrm{CoV}$ epidemics, the number of SARS patients who have been recognized with the developed symptoms such as seizures, myopathy, and rhabdomyolysis significantly increased (Tsai et al. 2005; Xu et al. 2005). Furthermore, in both CSF (Hung et al. 2003) and autopsied brain tissue (Xu et al. 2005), the viral RNA's presence was found to have neurotropic components of SARSCoV-1 (Paniz-Mondolfi et al. 2020; Romoli et al. 2020).

Experimental animal models of SARS caused by structurally similar CoVs during the epidemic of this virus in 2002 have provided valuable data on the involvement of nervous system in CoVs and SARS-CoV-1, which showed enormous potential for spreading throughout the CNS (Natoli et al. 2020). In the context of SARS, multiple animal models have been explored, including non-human primates, hamsters, ferrets, and mice. Consequently, many SARS animal models have been recognized, ranged from those in which virus replication is only detectable (such as B6 mice, young BALB/c) to those in which virus replication is followed by some severe symptoms and histopathology (such as non-human primates, ferrets, and hamsters) (Subbarao and Roberts 2006). A key finding that may unify SARS-CoV-1 from other species of CoVs, which had been identified earlier, is that this pathogen requires angiotensinconverting enzyme 2 (ACE2). Correspondingly, this is a membrane-bound protein expressed in several organs like CNS (Chen et al. 2020), as a cell entry receptor (Wong et al. 2004; Verdecchia et al. 2020). As well, animal studies have previously confirmed that although the olfactory pathway had been proposed as the main route for SARS-CoV-1 CNS entry route in animals, reports of SARS-related olfactory neuropathy in humans have been sparse (Hwang 2006; Kwong et al. 2020). Among animal models, mice transgenic for the expression of human ACE2 (hACE2) developed a moderate level of pulmonary disease; however, the overwhelming neurological disease (DeDiego et al. 2008; Perlman et al. 2020) is accompanied with chemokine and cytokine overexpression with cellular infiltration in the brain (McCray et al. 2007). On day 4 post-infection, lymphocyte and macrophage infiltrations occurred, which consequently led to pro-inflammatory cytokine release (such as IL-1, TNF- $\alpha$, and IL-6) not only in the pulmonary system, but also in the CNS. Therefore, by passing only 5 days from the intranasal infection with SARS-CoV-1, the investigated mice developed severe CNS symptoms such as lethargy, which established extensive brain involvement with $100 \%$ mortality (Tseng et al. 2007) (see Fig. 4).

Among all the involved regions of the brain in the mice inoculated with SARS-CoV-1, the brainstem has been confirmed to be severely infected by this virus (McCray et al. 2007; Netland et al. 2008). In these studies, one strange finding was that although SARS-CoV-1 produced general neuronal destruction within primary vital brainstem nuclei, including nucleus tractus solitarii, the vagus' dorsal motor nucleus, and area postrema, no pathological evidence on inflammation was observed. Therefore, it was proposed that the apoptosis process followed by severe dysregulated cytokine response could be considered the causes of neuronal death, which leads to animal death. Based on the similar animal studies, it was also hypothesized that the dorsal vagal complex's direct viral involvement, as a vital region of the brain orchestrating cardiorespiratory function, could be known as another cause of animal's death post-infection. In this regard, more studies demonstrated that while animals intracranially inoculated with low doses of SARS-CoV-1 showed that brain viral spreads very limitedly (Bradley and Bryan 2019), they succumbed to the neurological diseases related to this virus infection very quickly (Netland et al. 2008). Experimental animal studies with several other Betacoronaviruses have similarly proposed an association between most of Betacoronavirus infections and many longterm neurodegenerative disorders (Desforges et al. 2020). Although several reviews have been written in this regard, it is still difficult to ascertain how different neurological complications/symptoms are linked to the pathophysiology of SARS; either they are caused by direct involvement of the CNS with a virus, or they are developed by indirect involvement of CNS with hypoxia, sepsis, multi-organ failure, or any other mechanisms similar to these (Kwong et al. 2020) (see Table 1).

\section{Neuro-infection with MERS-CoV in animals}

The separation of an innovative Betacoronavirus from a patient in Saudi Arabia who died due to a severe acute respiratory syndrome, pneumonia, and multi-organ failure in June 2012 was the preliminary report of Middle East respiratory syndrome (MERS) (Zaki et al. 2012). Whereas SARS-CoV is transmitted to human beings from exotic animals in wet markets, MERS-CoV was indicated to be transferred from camels (Sabir et al. 2016). This virus was principally studied as a zoonotic virus that can non-sustainably spread animal-to-human and human-tohuman (Richard et al. 2017). Genomic sequence analyses demonstrated that MERS-CoV species can be found in several bat species from two bat families, namely Vespertilionidae and Nycteridae (Moreno et al. 2017; Wong et al. 2019). In general, virologists established that both camels and bats are the most expected animal reservoirs of MERS-CoV (Woo et al. 2007; Lau et al. 2013; Reusken et al. 2013; Azhar et al. 2014; Wernery et al. 2015; Bostanciklioğlu 2020). As discussed earlier, previously performed studies have revealed that the CNS, especially the brain, is one of the main target organs for most of Betacoronaviruses, in both animals and humans (Chan et al. 2013). MERS-CoV, which was found to be responsible for the MERS outbreak within and beyond 


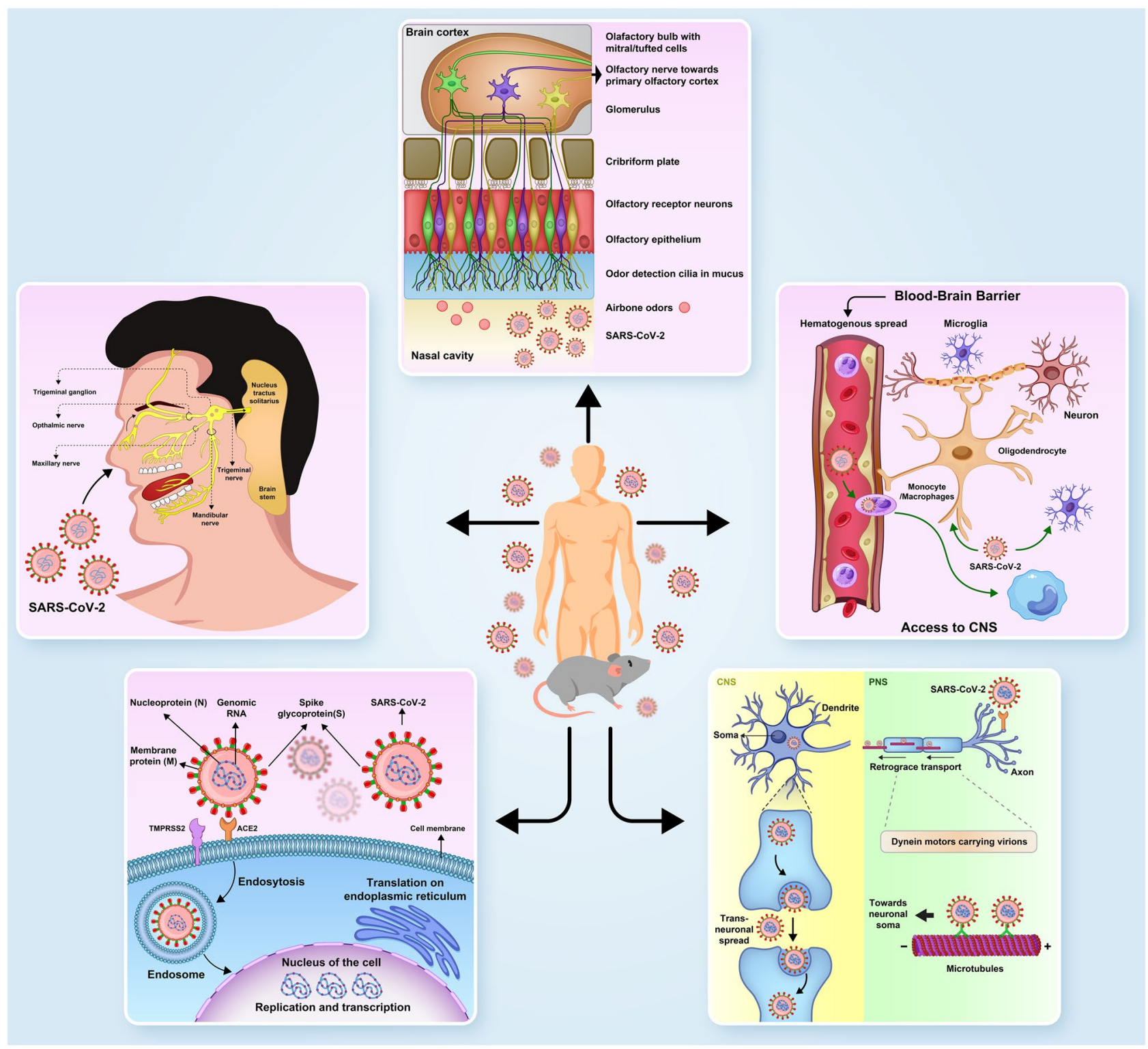

Fig. 4 Probable pathways of CoVs transmission from the periphery to the animals' or humans' CNS

the Middle East from 2012 to 2015 (Hijawi et al. 2013), enters host cells mainly via dipeptidyl peptidase 4 (DPP4), called CD26, which is present in the lower respiratory tract, kidney, small intestine, liver, and the immune system cells (Mattern et al. 1991; Boonacker and Van Noorden 2003; Liu et al. 2020). While the expression levels of DDP4 are low in the CNS, the presence of MERS-CoV in the brain was reported several times in both animals and humans (Bernstein et al. 2018). MERS-CoV infection presents with various clinical features ranged from asymptomatic or mild respiratory illness to fulminant SARS with extrapulmonary manifestations (Zumla et al. 2016). Moreover, the MERS' most common symptoms are the following: fever above $38^{\circ} \mathrm{C}$, chills, cough, shortness of breath, headache, myalgia, nausea, vomiting, and diarrhea (Nam et al. 2017). The casefatality rate of MERS is approximately 35\% (Sharif-Yakan and Kanj 2014). To obtain more knowledge about MERS, numerous experimental studies have been done during the past 8 years. As well, in order to compare MERS with SARSCoV-1, several studies on pigs were conducted. Scientists showed that despite the reason that the pigs are resistant to SARS-CoV-1 infections (Chen et al. 2005; Meekins et al. 2020), they are susceptible to infection with the MERSCoV (Vergara-Alert et al. 2017). Additionally, some studies conducted on cell lines demonstrated that some organs are more susceptible to MERS-CoV infection, including the respiratory tract, intestinal tract, genitourinary tract, liver, kidney, and neurons (Yin and Wunderink 2018). 


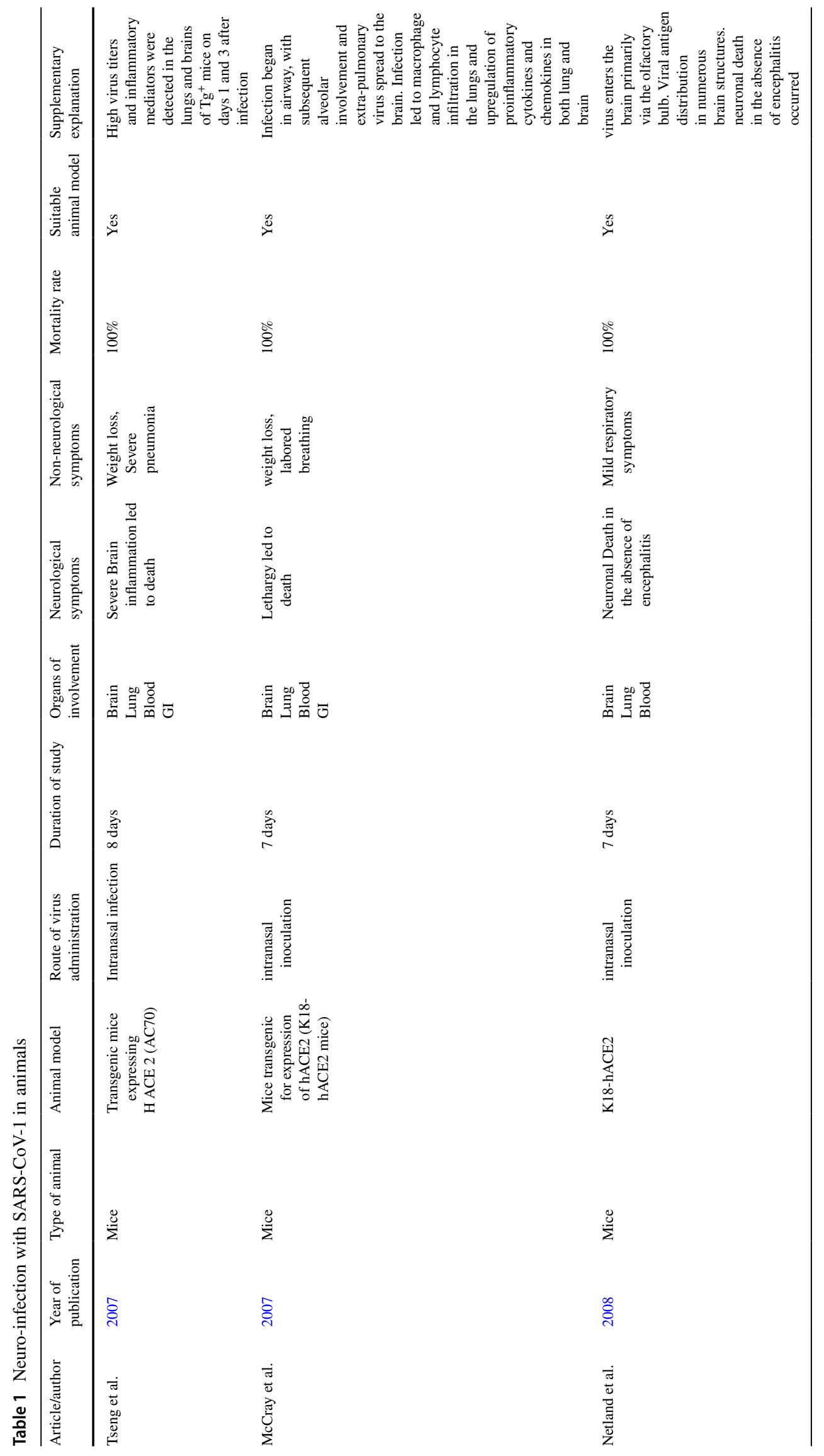


Using transgenic mice in animal studies established that intranasally administration of MERS-CoV may consequently lead to the virus's entrance to the brain, probably via the olfactory nerves. Subsequently, the virus rapidly spread to some definite regions of the brain such as the thalamus, and especially the brainstem, which is strongly susceptible to MERS-CoV infection. In laboratory mice inoculated with low doses of MERS-CoV, virus particles were found only in the brain and not in any other organ. This finding indicates that CNS infection is the leading cause of the high mortality rate observed in the infected mice ( $\mathrm{Li}$ et al. 2016a, b) (see Fig. 2).

Similar to SARS-CoV-1, MERS-CoV carries some significant clinical challenges because no definite anti-viral therapy has been proven for this infection yet. Although extensive efforts are in progress to discover effective virusbased or host-based therapeutic agents in this regard, several restrictions have prevented the progression in this field. For example, a limited number of suitable animal models performed to evaluate the potential treatments, an inadequate number of MERS cases for the current time, and lack of high pharmaceutical incentives to develop some novel antiviral therapies have altogether led to the lack of suitable anti-MERS drugs so far. The remaining threat of MERS$\mathrm{CoV}$ to the global health, even by passing some years from the first-time virus detection, offers an excellent occasion to deal with any existing complication in the way of developing a novel specific anti-coronaviral treatment. A highly efficient, multidisciplinary, universal collaborative system among virologists, physicians, and drug developers should be formed to conduct several clinical trials through currently available anti-coronaviral medications that have been proven as safe and effective under both in vitro and in vivo (Zumla et al. 2016).

In addition to these clinical trials, as the experimental animal model is one of the best types of studies performed in order to find effective medications for viral infections or vaccines, scientists should more focus on conducting more empirical studies to develop novel effective therapeutic agents for MERS-CoV infection and vaccines. The first step in performing animal studies is finding a suitable animal model that can mimic humans' specific disease patterns. For example, in rhesus macaques, MERS-CoV develops only mild type and self-limiting disease (Oliveira et al. 2020). Thus, these animal models are not practical for evaluating the proposed treatments for MERS disease (De Wit et al. 2013, Munster et al. 2013, Yao et al. 2014). In contrast to rhesus macaques, MERS-CoV induces a distributed and lethal infectious disease in the common marmosets with CNS involvement, which is meticulously similar to severe type of MERS disease in human beings (Falzarano et al. 2014; Chan et al. 2015a, b). Despite this similarity, MERS studies have been mostly conducted by applying other small animals, because the common marmoset is not very accessible and experiments performed on these small primates are technically demanding. On the other hand, unlike SARS$\mathrm{CoV}-1$, most of small animals, such as hamsters, ferrets, and rabbits, are not susceptible to MERS-CoV infection (de Wit et al. 2013; Coleman et al. 2014; Leist and Cockrell 2020).

Zhao et al. in their study, showed that intranasal administration of adenoviral vectors expressing human DPP4 followed by MERS-CoV inoculation could rapidly increase the mice's susceptibility to MERS-CoV infection. However, this disease is relatively mild and confined to the respiratory tract, and besides, it cannot infect the CNS (Zhao et al. 2014). In contrast to this study, Agrawal et al. in their research indicated that MERS-CoV could induce a severe pulmonary and disseminated infection in transgenic mice that express human DPP4. Correspondingly, this animal model is currently known as the best available small animal model for MERS (Agrawal et al. 2015). Of note, all potential anti-MERS-CoV treatment options identified by in vitro anti-viral assays should be further evaluated in this transgenic mouse model. More studies in this regard found that mice, guinea pigs, and hamsters are not susceptible to experimental MERS-CoV infection, mainly because their homologous DPP4 molecules do not act as receptors for MERS-CoV cell entry (Decaro and Lorusso 2020) (see Table 2).

\section{Neuro-infection with SARS-CoV-2 in animals}

Although MERS-CoV has not been eradicated from the world yet, another extremely pathogenic CoV, named SARSCoV-2, appeared in December 2019 in Wuhan, China. This novel $\mathrm{CoV}$, which firstly caused a nationwide epidemic of severe acute pneumonia, called COVID-19, quickly spread in and out of China, and then developed a fatal pandemic disease. Thereafter, it was determined as a global public health emergency (Organization 2020a, b, c, d, e). SARS-CoV-2, which is in the identical Betacoronavirus clade similar to SARS-CoV-1 and MERS-CoV, shares a highly homological sequence with SARS-CoV-1 (Jaimes et al. 2020). Like many other CoVs, it is stated that SARS-CoV-2 may have been spread from a potential bat reservoir to human beings by an unknown intermediate animal host, which is still under investigation (Lu et al. 2020a, b, c) (see Fig. 1).

Animal models, principally non-human primate models, are immediately required to find the answers to basic inquiries that could not be responded to by studying COVID-19 patients. These animal models are also essential for assessing anti-viral medications, innovating novel therapies, and finding an experimental vaccine. In a study done by $\mathrm{Lu}$ et al., two non-human primates' families were experimentally inoculated with SARS-CoV-2 as follows: (1) Old World monkeys (Macaca mulatta, Macaca fascicularis), and (2) New World 


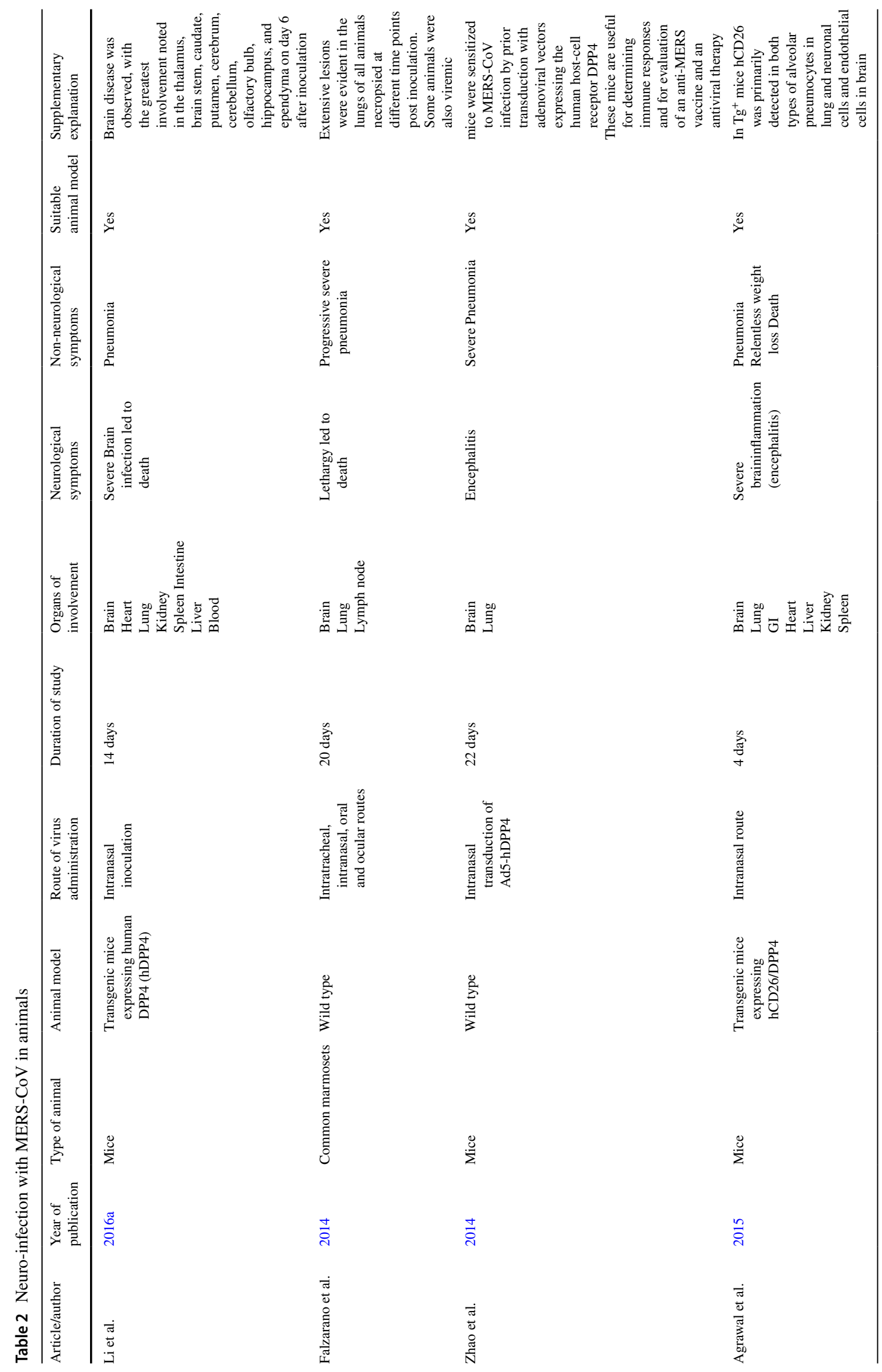


monkeys (Callithrix jacchus). Subsequently, their clinical signs and symptoms were reported. Furthermore, tissue samples were gathered in order to evaluate viral shedding and viremia, and to perform histopathological investigations. Although this study showed that Macaca mulatta is the most susceptible genus to be infected by SARS-CoV-2 (Lu et al. $2020 \mathrm{a}, \mathrm{b}, \mathrm{c}$ ), the presence or pathophysiology of this virus in the CNS tissue was not evaluated unfortunately. So, more experiments are still needed to evaluate the neurotropism of SARS-CoV-2 in animal models, in order to find out how this virus invades the CNS and then causes several neurological symptoms as seen in infected humans.

As mentioned earlier, $\mathrm{CoV}$ infections are not always restricted to the respiratory system, and some strains of them can directly attack the CNS or indirectly affect it, causing several neurological diseases. As we noted in the previous sections of this review, such neuroinvasive tendency of CoVs has been recognized only in all Betacoronaviruses, including MHV (Horzinek and In 1995; Ganem 3rd 1996; Paybast et al. 2020), HCoV-229E, HCoV-OC43 (Rossen et al. 1995; Yashavantha Rao and Jayabaskaran 2020), PHEV (Decaro and Lorusso 2020), SARS-CoV-1 (Tsai et al. 2005; Xu et al. 2005), and MERS-CoV (Bernstein et al. 2018).

It is currently apparent that, similar to SARS-CoV-1, the ACE2 receptor is the primary receptor for SARS-CoV-2 host's cell entry. Besides the kidney, liver, lung, and heart that have been primarily discovered as the original sites of ACE2 expression, it is now become evident that this receptor is predominantly expressed in all endothelium as well as neural tissues (Harmer et al. 2002; Xia and Lazartigues 2008; Najjar et al. 2020). Although immunohistochemistry (IHC) has failed to demonstrate ACE2 receptors in neurons or glial cells, it confirmed their high expression levels within the CNS vasculature (Hamming et al. 2004; Toljan 2020a, b). Further investigations performed in this regard have demonstrated that despite high-level expression of ACE2 mRNA in numerous CNS's structures, it is translated to protein and it is only limited to the CNS regions. Based on our understanding obtained from the SARS-CoV-1 studies, the virus's spike protein plays a crucial role in facilitating viral entry into target cells. Notably, when the S1 unit of the S protein binds to a cellular receptor, the virus attaches to the target cells' surface.

Additionally, when cell entry necessitates S protein priming by cellular proteases, SARS-CoV-1 engages the cellular surface protease TMPRSS2 for S protein priming (Glowacka et al. 2011; Chen et al. 2020). Accordingly, TMPRSS2 is scarcely present in some brain parts, including the brainstem, insula, globus pallidus, postcentral gyrus, and temporal and occipital lobes (Lukassen et al. 2020). As ACE2 receptor is known as a critical factor in the SARS-CoV-1 transmissibility (Li et al. 2005; Abdelrahman et al. 2020) and given the fact that both SARS-CoV-1 and 2 share more than $75 \%$ amino acid identity, it is currently believed that SARS-CoV-2 employs ACE2 along with TMPRSS2 for host cell entry (Hoffmann et al. 2020).

One of the most common neurological manifestations of the COVID-19 is the impaired sense of smell, hyposmia, or anosmia, which may happen even in infected patients, but it shows no disease's symptoms (Hopkins and Kumar 2020). The pathophysiology of such olfactory dysfunction induced by SARS-CoV-2 infection is still unclear; therefore, conducting more animal models could help scientists uncover the underlying mechanisms. Studies on mice showed that endogenous reprogramming induced by tissue injuries could result in the de-differentiation of neuronal progenitors and suppression of ongoing neurogenesis, and all these processes could theoretically abrogate olfactory system function eventually (Lin et al. 2017). However, more studies are needed regarding that this finding could suggest why inflammation induced by SARS-CoV-2 can impair a sense of smell.

Besides the olfactory route (olfactory receptor neurons (OSNs) of the olfactory epithelium, olfactory bulb, and glomeruli, and their projections), which are used by neurotropic CoVs to transmit from the upper respiratory tract into the CNS, three other probable pathways have also been recognized that help these CoVs to reach the CNS from the periphery, which are as follows: (1) Neurotropic CoVs in the lower respiratory tract infect monocytes, neutrophils, lymphocytes, and macrophages of the alveoli capillaries and then spread via hematogenous transmission to get the BBB. They cross it through diapedesis and then infect neuronal and glial cells (Alquisiras-Burgos et al. 2020; Uversky et al. 2020); (2) Respiratory CoVs can also reach the CNS via retrograde neuronal dissemination. In fact, neurotropic $\mathrm{CoVs}$ firstly infect PNS, and following peripheral nerve infection, they access the CNS by axonal transport systems (Koyuncu et al. 2013). Briefly, several peripheral organs are used as entrance points for the neurotropic CoVs. These organs' innervation is connected to the CNS either through their sensory or through motor nerve endings (II and McGavern 2015). An expanding number of cases have recognized viral particles in peripheral nerves. The present discovery clarifies the effect of SARS-CoV-2 on a few neurological problems and supports a converging hypothesis that axonal and transsynaptic transmissions play vital roles in the deterioration of patients affected with COVID-19; (3) Attachment of the spike protein of the neurotropic CoVs to the ACE2 receptors expressed on the capillary endothelium of $\mathrm{BBB}$ may further help the viruses to enter the CNS through both attacking the vascular system and damaging the BBB or blood-CSF barrier (BCSFB). Furthermore, one consequence of the elevated cytokine and chemokine production is the increased BBB permeability, which may possibly facilitate widespread entry of SARS-CoV into the CNS; and (4) 
Trigeminal nerve: Neurotropic CoVs within the mucosa of the nose could attack the trigeminal nerve sensory axons and consequently induce some neuronal complications. This has been established when SARS-CoV-2 was found in trigeminal ganglion and axonal degeneration was also observed in the trigeminal nerve of six autopsied COVID-19 patients (Meinhardt et al. 2020).

Nonetheless, regardless of whether these perceptions are due to an insusceptible reaction or direct invasion, the infection could not be confirmed (UR and Verma 2020). One more exciting characteristic of the SARS-CoV-2-trigeminal nerve connection is its trigeminal route's association with the brain caudal regions and nuclei related to respiration. Correspondingly, this fact promotes the concept that SARSCoV-2 is able to blemish the nucleus tractus solitarius (NTS) (Satarker and Nampoothiri 2020). This connectivity could subsequently lead to microvascular clotting, pulmonary edema, and cytokine storm in patients affected by COVID19 (UR and Verma 2020) (see Fig. 4).

Further studies with more mouse models of SARS-CoV-2 infection demonstrated that although ACE2 and TMPRSS2 are obviously expressed in sustentacular cells of the olfactory epithelium, they are rarely expressed in olfactory receptor neurons. This finding suggested that the sustentacular cells are the primary cells involved in the SARS-CoV-2 entry to both the olfactory system and the CNS. Moreover, calculation of the SARS-CoV-2 entry proteins' expression levels demonstrated that such increase more significantly occurs in old-age animals than in younger ones. This result could describe why older individuals are more susceptible to the infection induced by this virus (Bilinska et al. 2020) (see Fig. 4).

Another neurological complication caused by SARSCoV-2 infection is dysgeusia. Previous animal studies showed that the high level of ACE2 protein density in the nucleus of the solitary tract (Yamazato et al. 2011) as a result could make a possible neuroinvasive path either by continuous local or by retrograde axonal transport in the vagus nerve, thereby describing the central source of dysgeusia (Toljan 2020a, b). The role of ACE2 in SARS-CoV-2 infection has been finalized by the administration of angiotensinconverting enzyme inhibitors and angiotensin II receptor blockers in the experimental animal models. Several studies showed that although both medicine categories are able to increase animals' susceptibility to SARS-CoV-2 infection via upregulating the expression level of ACE2 in them (Ishiyama et al. 2004; Organization 2020a, b, c, d, e), their effects on different animal tissues could be totally diverse (Kuster et al. 2020). Besides ACE2 and TMPRSS2, further studies indicated that SARS-CoV-2 could also invade host cells via the novel route of CD147 spike protein (SP). As well, SP binds to CD147, which is a receptor on the host cells that is extensively present in both animals' and humans'
CNS (Podvin et al. 2018), thereby mediating the viral attack (Chen et al. 2020) (see Fig. 4).

As mentioned earlier, this new $\mathrm{CoV}$ is very similar to SARS-CoV-1 in its homological sequence, cellular entry, and pathogenesis. It was indicated that some CoVs such as IBV, SARS-CoV-1, and MERS-CoV can attack the brainstem from the cardiorespiratory system through a synapseconnected route (trans-synaptic transfer) in both mice and human beings (Chasey and Alexander 1976; Matsuda et al. 2004; Clark et al. 2020). The number of studies hypothesizing that similar to other CoVs, SARS-CoV-2 may also cause acute respiratory failure due to its potential to invade the brainstem where the nucleus of the solitary tract and nucleus ambiguous are there, increased in recent years. While these nuclei receive their afferent fibers from the mechanoreceptors and chemoreceptors of the respiratory system (Kalia and Mesulam 1980; Hadziefendic and Haxhiu 1999; Raux et al. 2000; Machado and Gutierrez 2020), their efferent fibers develop to airway smooth muscles, glands, and blood vessels. Accordingly, this kind of innervations shows that both animals and humans affected by SARS-CoV-2 may die due to dysfunctions in their brainstem's cardiorespiratory centers (Matsuda et al. 2004; Bernstein et al. 2018; Khan et al. 2020).

In this regard, the initial reports proposed that only a small number of patients with SARS-CoV-2 present neurological manifestations. A new study demonstrated that around $90 \%$ of patients with severe COVID-19 display some neurologic signs and symptoms such as headache, anosmia/hyposmia, dysgeusia/hypogeusia, nausea, vomiting, or even viral encephalitis, hemorrhagic necrosis of mesial brain structures, including the medial temporal lobes and thalami (Wilson and Jack 2020), acute cerebrovascular attacks, and the impaired mental state such as confusion, dizziness, or the decreased level of consciousness (Mao et al. 2020). In summary, this study attempted to indicate the significance of being aware of the chance of respiratory failure due to SARS-CoV-2-induced neuroinvasion in patients with severe COVID-19. Thus, the importance of providing suitable experimental animal models is undeniable, since these models could help researchers to better understand mechanisms of virus entry and attack medullary neurons of the CNS (Huang et al. 2020), in order to find the best way of the prevention or treatment of this disease and in general to support proposing subtle strategies toward handling this public health emergency ( $\mathrm{Li}$ et al. 2020).

Earlier studies with rhesus macaques showed that this animal could be considered an appropriate model for SARS$\mathrm{CoV}-2$ infection. For example, Bao et al. in their study used this animal model of SARS-CoV-2 infection to assess the risk factors involved in reinfection (relapse). As a result, they demonstrated that while the chance of viral RNA detection in many organs, including the brain, was absolutely high in 


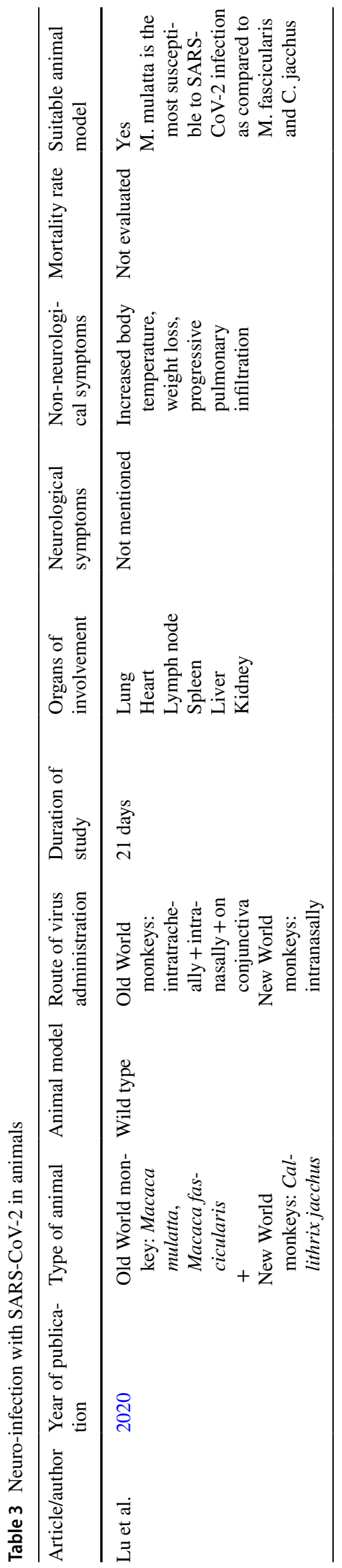

primarily infected animals, qRT-PCR was not able to detect any viral replication at 5 days post-reinfection (re-exposure) (Bao et al. 2020).

In another study, Munster et al. have recently established that the rhesus macaque model of SARS-CoV-2 is in line with the majority of human reported cases of COVID-19. For example, in this animal model, radiographic pulmonary infiltration, virus shedding pattern, multi-organ involvement, and disease severity could detect no significant virus loads in different CNS regions (such as frontal lobes, brainstems, and cerebellums), which are similar to patients with SARS-CoV-2 infection. Consequently, they concluded that a suitable animal model proposed for COVID-19 would be the one that reflects the neurological features of this neurotropic virus (Munster et al. 2020). In summary, it could be expressed that many questions on the neurological manifestation of COVID-19 still remain unanswered until the time that a suitable animal model will be developed by scientists (see Table 3).

\section{Conclusion}

Numerous animal and human studies have demonstrated that CoVs, especially Betacoronaviruses, are pathogens with neuroinvasive potentials. Many COVID-19 patients, like patients affected by SARS and MERS in the past, show the signs and symptoms of CNS involvement ranged from headache, nausea, vomiting, and confusion to anosmia, ageusia, encephalomyelitis, stroke, or even death. Furthermore, susceptible individuals like those patients with immunocompetent/immunosuppressed, respiratory diseases, cardiovascular diseases, and metabolic disorders may experience even some post-infectious immune-mediated complications such as neurodegeneration in the convalescent period. SARS-elucidating SARS-CoV-2 pathogenesis and stepping toward developing practical therapeutic approaches or specific antivirals that have been hampered by the lack of a suitable animal experimental model, which is replicable and can imitate the human disease.

Furthermore, to understand the potential mechanisms of SARS-CoV-2 neuroinvasion, it is reasonable to inspect the neuroinvasive actions of the known CoVs that have been tested for a more extended timeframe. The two essential common routes proposed for viral neuroinvasion that have been well-designated up to now are neuronal and hematogenous. It has been exhibited that $\mathrm{CoVs}$ can utilize each one of these routes to achieve CNS infiltration. Incidentally, scientists have speculated that there may be other different viral transmission pathways from the periphery to the CNS, as well.

There are various little and large animal models that can be used by examiners to investigate significant expressions 
of SARS-CoV-2 disease, particularly concerning its pathology and transferring, and host reactions to this $\mathrm{CoV}$, only to assist in setting up the safety as well as the viability of expected vaccines and drugs. Future investigations should normalize challenge stocks, tests, and conventions to permit the correlations between various applicant interventions. Model animals are also expected to evaluate immunization-related improved respiratory illness as well as the foundation of positive control for this sickness that will be significant.

Persisted improvement and advancement of experimental animal models proposed for SARS-CoV-2 disease will add to the advancements in immunizations for this disease with the vaccine, medicinal compositions, and different counteractions. In addition, extensive medical assays should be in progress to evaluate numerous candidate prophylactic and curative medications in human beings. At the end, the results of these clinical-adequacy assessments will permit excellent chances for the back-approval and improvement of these models.

Briefly, appropriate animal experimental models of SARS-CoV-2 infection are currently needed to better understand the mechanisms of COVID-19-induced neuropathogenesis and to evaluate any CNS or even systemic viral antigen/RNA or inflammatory markers that could anticipate the chance of brain parenchymal infection. The results of such experimental studies can help the physicians to be more prepared to prevent any probable neurological complication.

As the first step, experimental studies should be designed to evaluate animals' susceptibility to SARSCoV-2 infection and focus on animal models that can show neurotropic properties of SARS-CoV-2. Therefore, several clinical questions on the CNS involvement of SARSCoV-2 infection, which have been raised since the beginning of the current pandemic, both in the acute phase and during the chronic phase, will be answered. Additionally, investigations on these animal models could address which one of the routes of SARS-CoV-2 transmission (intravenous or intranasal) can affect the chance of developing severe neurological complications such as neuroinflammation or neurodegeneration. We concluded that animal models, particularly non-human primate models, are urgently needed for answering the critical questions that have not been answered in clinical patients so far. On the other hand, regarding the COVID-19 neuroinvasive potential, further animal and translational studies are needed to find effective anti-viral therapeutic agents with the ability of crossing the BBB. Interpretation of all future discoveries to humans will empower us to clarify pathogenesis mechanisms of this disease, create and assay prevention strategies and interventions, and fight against SARS-CoV-2 disease to make the world normal again.

\section{References}

Abdelrahman Z, Li M, Wang X (2020) Comparative review of SARSCoV-2, SARS-CoV, MERS-CoV, and influenza a respiratory viruses. Front Immunol 11:2309

Agrawal AS, Garron T, Tao X, Peng B-H, Wakamiya M, Chan T-S, Couch RB, Tseng C-TK (2015) Generation of a transgenic mouse model of Middle East respiratory syndrome coronavirus infection and disease. J Virol 89(7):3659-3670

Almaghaslah D, Kandasamy G, Almanasef M, Vasudevan R, Chandramohan S (2020) Review on the coronavirus disease (COVID-19) pandemic: its outbreak and current status. Intl J Clin Pract 74(11):e13637

Alquisiras-Burgos I, Peralta-Arrieta I, Alonso-Palomares LA, Zacapala-Gómez AE, Salmerón-Bárcenas EG, Aguilera P (2020) Neurological complications associated with the bloodbrain barrier damage induced by the inflammatory response during SARS-CoV-2 infection. Mol Neurobiol 1-16

Azhar EI, El-Kafrawy SA, Farraj SA, Hassan AM, Al-Saeed MS, Hashem AM, Madani TA (2014) Evidence for camel-tohuman transmission of MERS coronavirus. N Engl J Med 370(26):2499-2505

Azhideh A (2020) COVID-19 neurological manifestations. International Clinical Neuroscience Journal 7(2):54-54

Bailey M, Persons A, Napier C (2017) Basal ganglia and limbic striatal regions are differentially affected by pramipexole: D3 receptormediated changes in markers of synaptic strength (P2. 028), AAN Enterprises

Bao L, Deng W, Gao H, Xiao C, Liu J, Xue J, Lv Q, Liu J, Yu P, Xu $Y$ (2020) Reinfection could not occur in SARS-CoV-2 infected rhesus macaques. BioRxiv

Barnes HL, Chrisman CL, Mariani CL, Sims M, Alleman AR (2004) Clinical signs, underlying cause, and outcome in cats with seizures: 17 cases (1997-2002). J Am Vet Med Assoc 225(11):1723-1726

Bender SJ, Weiss SR (2010) Pathogenesis of murine coronavirus in the central nervous system. J Neuroimmune Pharmacol 5(3):336-354

Bernstein H-G, Dobrowolny H, Keilhoff G, Steiner J (2018) Dipeptidyl peptidase IV, which probably plays important roles in Alzheimer disease (AD) pathology, is upregulated in $\mathrm{AD}$ brain neurons and associates with amyloid plaques. Neurochem Int 114:55-57

Bilinska K, Jakubowska P, von Bartheld CS, Butowt R (2020) Expression of the SARS-CoV-2 entry proteins, ACE2 and TMPRSS2, in cells of the olfactory epithelium: identification of cell types and trends with age. ACS Chem Neurosci

Boettcher IC, Steinberg T, Matiasek K, Greene CE, Hartmann K, Fischer A (2007) Use of anti-coronavirus antibody testing of cerebrospinal fluid for diagnosis of feline infectious peritonitis involving the central nervous system in cats. J Am Vet Med Assoc 230(2):199-205

Boonacker E, Van Noorden CJ (2003) The multifunctional or moonlighting protein CD26/DPPIV. Eur J Cell Biol 82(2):53-73

Bostanciklioğlu M (2020) SARS-CoV2 entry and spread in the lymphatic drainage system of the brain. Brain Behav Immun

Bradley BT, Bryan A (2019) Emerging respiratory infections: The infectious disease pathology of SARS, MERS, pandemic influenza, and Legionella. Seminars in diagnostic pathology, Elsevier

Cabirac GF, Soike KF, Zhang J-Y, Hoel K, Butunoi C, Cai G-Y, Johnson S, Murray RS (1994) Entry of coronavirus into primate CNS following peripheral infection. Microb Pathog 16(5):349-357

Chakravarty D, Saadi F, Kundu S, Bose A, Khan R, Dine K, Kenyon LC, Shindler KS, Sarma JD (2020) CD4 deficiency causes poliomyelitis and axonal blebbing in murine coronavirus-induced neuroinflammation. J Virol 94(14) 
Chakravarty D, Sarma JD (2021) Murine- $\beta$-coronavirus-induced neuropathogenesis sheds light on CNS pathobiology of SARSCoV2. J Neurovirol 1-20

Chan JF-W, Yao Y, Yeung M-L, Deng W, Bao L, Jia L, Li F, Xiao C, Gao H, Yu P (2015a) Treatment with lopinavir/ritonavir or interferon- $\beta 1 \mathrm{~b}$ improves outcome of MERS-CoV infection in a nonhuman primate model of common marmoset. J Infect Dis 212(12):1904-1913

Chan JF, Chan K-H, Kao RY, To KK, Zheng B-J, Li CP, Li PT, Dai J, Mok FK, Chen H (2013) Broad-spectrum antivirals for the emerging Middle East respiratory syndrome coronavirus. J Infect 67(6):606-616

Chan JF, Lau SK, To KK, Cheng VC, Woo PC, Yuen K-Y (2015b) Middle East respiratory syndrome coronavirus: another zoonotic betacoronavirus causing SARS-like disease. Clin Microbiol Rev 28(2):465-522

Chasey D, Alexander D (1976) Morphogenesis of avian infectious bronchitis virus in primary chick kidney cells. Adv Virol 52(1-2):101-111

Chen R, Yu J, Wang K, Chen Z, Wen C, Xu Z (2020) The spatial and cell-type distribution of SARS-CoV-2 receptor ACE2 in human and mouse brain. bioRxiv

Chen W, Yan M, Yang L, Ding B, He B, Wang Y, Liu X, Liu C, Zhu H, You B (2005) SARS-associated coronavirus transmitted from human to pig. Emerg Infect Dis 11(3):446

Chen Y, Lear T, Evankovich J, Larsen M, Lin B, Alfaras I, Kennerdell J, Salminen L, Camarco D, Lockwood K (2020) A high throughput screen for TMPRSS2 expression identifies FDA-approved and clinically advanced compounds that can limit SARS-CoV-2 entry.

Cheng Q, Yang Y, Gao J (2020) Infectivity of human coronavirus in the brain. EBioMedicine 56:102799

Cheng VC, Lau SK, Woo PC, Yuen KY (2007) Severe acute respiratory syndrome coronavirus as an agent of emerging and reemerging infection. Clin Microbiol Rev 20(4):660-694

Chiow K, Phoon M, Putti T, Tan BK, Chow VT (2016) Evaluation of antiviral activities of Houttuynia cordata Thunb. extract, quercetin, quercetrin and cinanserin on murine coronavirus and dengue virus infection. Asian Pac J Trop Med 9(1):1-7

Clark JJ, Penrice-Randal R, Sharma P, Kipar A, Dong X, Davidson AD, Williamson MK, Matthews DA, Turtle L, Prince T (2020) Sequential infection with influenza A virus followed by severe acute respiratory syndrome coronavirus 2 (SARS-CoV-2) leads to more severe disease and encephalitis in a mouse model of COVID-19. bioRxiv

Coleman CM, Matthews KL, Goicochea L, Frieman MB (2014) Wildtype and innate immune-deficient mice are not susceptible to the Middle East respiratory syndrome coronavirus. J Gen Virol 95(Pt 2):408

Dandekar AA, Wu GF, Pewe L, Perlman S (2001) Axonal damage is $\mathrm{T}$ cell mediated and occurs concomitantly with demyelination in mice infected with a neurotropic coronavirus. J Virol 75(13):6115-6120

De Groot R, Baker S, Baric R, Enjuanes L, Gorbalenya A, Holmes K (2011) King AMQ, Lefkowitz E, Adams MJ, Carstens EB Family Coronaviridae. Ninth Report of the International Committee on Taxonomy of Viruses: 806-828

de Wit E, Prescott J, Baseler L, Bushmaker T, Thomas T, Lackemeyer MG, Martellaro C, Milne-Price S, Haddock E, Haagmans BL (2013) "The Middle East respiratory syndrome coronavirus (MERS-CoV) does not replicate in Syrian hamsters." PloS One 8(7)

Decaro N, Lorusso A (2020) Novel human coronavirus (SARSCoV-2): a lesson from animal coronaviruses. Vet Microbiol 108693

DeDiego ML, Pewe L, Alvarez E, Rejas MT, Perlman S, Enjuanes L (2008) Pathogenicity of severe acute respiratory coronavirus deletion mutants in hACE-2 transgenic mice. Virology 376(2):379-389

Desforges M, Le Coupanec A, Dubeau P, Bourgouin A, Lajoie L, Dubé M, Talbot PJ (2020) Human Coronaviruses and Other Respiratory Viruses: Underestimated Opportunistic Pathogens of the Central Nervous System? Viruses 12(1):14

Diaz JV, Poma R (2009) Diagnosis and clinical signs of feline infectious peritonitis in the central nervous system. Can Vet $\mathrm{J}$ 50(10): 1091

Dickinson PJ, Bannasch M, Thomasy SM, Murthy VD, Vernau KM, Liepnieks M, Montgomery E, Knickelbein KE, Murphy B, Pedersen NC (2020) Antiviral treatment using the adenosine nucleoside analogue GS-441524 in cats with clinically diagnosed neurological feline infectious peritonitis. J Vet Intern Med 34(4):1587-1593

Doenges SJ, Weber K, Dorsch R, Fux R, Fischer A, Matiasek LA, Matiasek K, Hartmann K (2016) Detection of feline coronavirus in cerebrospinal fluid for diagnosis of feline infectious peritonitis in cats with and without neurological signs. J Feline Med Surg 18(2):104-109

Domingues R, Mendes-Correa M, FBVdM L, Sabino E, Claro I, Ferreira N, Romano C, JGd J, DWdCL S, Salarini D (2020) First Case Of SAR-Coronavirus-2 Sequencing In The Cerebrospinal Fluid Of A Patient With Suspected CNS Demyelinating Disease.

Dörries R, Schwender S, Imrich H, Harms H (1991) Population dynamics of lymphocyte subsets in the central nervous system of rats with different susceptibility to coronavirus-induced demyelinating encephalitis. Immunology 74(3):539

Drosten C, Günther S, Preiser W, Van Der Werf S, Brodt H-R, Becker S, Rabenau H, Panning M, Kolesnikova L, Fouchier RA (2003) Identification of a novel coronavirus in patients with severe acute respiratory syndrome. N Engl J Med 348(20):1967-1976

Fallahi R, Abedini F, Shokri GR (2019) Molecular detection of mouse hepatitis virus in laboratory mouse colonies. Iran J Veterinary Sci Technol 11(2):69-72

Falzarano D, de Wit E, Feldmann F, Rasmussen AL, Okumura A, Peng X, Thomas MJ, van Doremalen N, Haddock E, Nagy L (2014) Infection with MERS-CoV causes lethal pneumonia in the common marmoset. PLoS Pathogens 10(8)

Fehr AR, Perlman S (2015) Coronaviruses: an overview of their replication and pathogenesis. Springer, Coronaviruses, pp 1-23

Felsenstein S, Herbert JA, McNamara PS, Hedrich CM (2020) COVID19: Immunology and treatment options. Clin Immunol 108448

Fleming J, Trousdale M, El-Zaatari F, Stohlman S, Weiner L (1986) Pathogenicity of antigenic variants of murine coronavirus JHM selected with monoclonal antibodies. J Virol 58(3):869-875

Fleming J, Trousdale M, Stohlman S, Weiner L (1987) Pathogenic characteristics of neutralization-resistant variants of JHM coronavirus (MHV-4). Springer, Coronaviruses, pp 333-342

Foley JE, Leutenegger C (2001) A review of coronavirus infection in the central nervous system of cats and mice. J Vet Intern Med 15(5):438-444

Fung TS, Liu DX (2021) Similarities and Dissimilarities of COVID-19 and Other Coronavirus Diseases. Annu Rev Microbiol 75

Ganem D 3rd (1996) In Fields Virology, 3rd edn. Philadelphia, Fields BN, Knipe DM, Howley PM, Lippincott Raven

Gao W, He W, Zhao K, Lu H, Ren W, Du C, Chen K, Lan Y, Song D, Gao F (2010) Identification of NCAM that interacts with the PHE-CoV spike protein. Virology Journal 7(1):254

Giannis D, Ziogas IA, Gianni P (2020) Coagulation disorders in coronavirus infected patients: COVID-19, SARS-CoV-1, MERS-CoV and lessons from the past. J Clin Virol 127:104362

Glowacka I, Bertram S, Müller MA, Allen P, Soilleux E, Pfefferle S, Steffen I, Tsegaye TS, He Y, Gnirss K (2011) Evidence that TMPRSS 2 activates the severe acute respiratory syndrome coronavirus spike protein for membrane fusion and reduces viral control by the humoral immune response. J Virol 85(9):4122-4134 
Gomes MGM, Aguas R, Corder RM, King JG, Langwig KE, SoutoMaior C, Carneiro J, Ferreira MU, Penha-Goncalves C (2020) Individual variation in susceptibility or exposure to SARS-CoV-2 lowers the herd immunity threshold. MedRxiv

Hadziefendic S, Haxhiu MA (1999) CNS innervation of vagal preganglionic neurons controlling peripheral airways: a transneuronal labeling study using pseudorabies virus. J Auton Nerv Syst 76(2-3):135-145

Hamming I, Timens W, Bulthuis M, Lely A, Navis G, van Goor H (2004) Tissue distribution of ACE2 protein, the functional receptor for SARS coronavirus. A first step in understanding SARS pathogenesis. The Journal of Pathology: A Journal of the Pathological Society of Great Britain and Ireland 203(2):631-637

Harmer D, Gilbert M, Borman R, Clark KL (2002) Quantitative mRNA expression profiling of ACE 2, a novel homologue of angiotensin converting enzyme. FEBS Lett 532(1-2):107-110

Herndon RM, Griffin DE, McCormick U, Weiner LP (1975) Mouse hepatitis virus-induced recurrent demyelination: A preliminary report. Arch Neurol 32(1):32-35

Hijawi B, Abdallat M, Sayaydeh A, Alqasrawi S, Haddadin A, Jaarour N, El Sheikh S, Alsanouri T (2013) Novel coronavirus infections in Jordan, April 2012: epidemiological findings from a retrospective investigation. EMHJ-Eastern Mediterr Health J 19(1):S12-S18

Hoffmann M, Kleine-Weber H, Schroeder S, Krüger N, Herrler T, Erichsen S, Schiergens TS, Herrler G, Wu NH, Nitsche A (2020) SARS-CoV-2 cell entry depends on ACE2 and TMPRSS2 and is blocked by a clinically proven protease inhibitor. Cell

Holmes KV (1999) Coronaviruses (Coronaviridae). Encyclopedia Virol 291

Hopkins C, Kumar N (2020) Loss of sense of smell as marker of COVID-19 infection. Ear, Nose and Throat surgery body of United Kingdom. Retrieved 28

Horzinek M, In K (1995) The Coronaviridae. Siddell SG, editor, New York: Plenum Press

Huang C, Wang Y, Li X, Ren L, Zhao J, Hu Y, Zhang L, Fan G, Xu J, Gu X (2020) Clinical features of patients infected with 2019 novel coronavirus in Wuhan, China. The Lancet 395(10223):497-506

Hussein HA, Hassan RY, Chino M, Febbraio F (2020) Point-of-Care Diagnostics of COVID-19: From Current Work to Future Perspectives. Sensors 20(15):4289

Hung EC, Chim SS, Chan PK, Tong YK, Ng EK, Chiu RW, Leung CB, Sung JJ, Tam JS, Lo YM (2003) Detection of SARS coronavirus RNA in the cerebrospinal fluid of a patient with severe acute respiratory syndrome. Clin Chem 49(12):2108-2109. https://doi. org/10.1373/clinchem.2003.025437

Hwang C (2006) Olfactory Neuropathy in Severe Acute Respiratory Syndrome: Report of A Case. Acta Neurol Taiwan 15(1):26

II PAS, McGavern DB (2015) Portals of viral entry into the central nervous system. The Blood-Brain Barrier in Health and Disease, Volume Two: Pathophysiology and Pathology 23

Ishiyama Y, Gallagher PE, Averill DB, Tallant EA, Brosnihan KB, Ferrario CM (2004) Upregulation of angiotensin-converting enzyme 2 after myocardial infarction by blockade of angiotensin II receptors. Hypertension 43(5):970-976

Jacomy H, Fragoso G, Almazan G, Mushynski WE, Talbot PJ (2006) Human coronavirus OC43 infection induces chronic encephalitis leading to disabilities in BALB/C mice. Virology 349(2):335-346

Jaimes JA, André NM, Chappie JS, Millet JK, Whittaker GR (2020) Phylogenetic analysis and structural modeling of SARS-CoV-2 spike protein reveals an evolutionary distinct and proteolyticallysensitive activation loop. J Mol Biol

Kalia M, Mesulam MM (1980) Brain stem projections of sensory and motor components of the vagus complex in the cat: II. Laryngeal, tracheobronchial, pulmonary, cardiac, and gastrointestinal branches. Journal of Comparative Neurology 193(2):467-508

Khan S, Ali A, Siddique R, Nabi G (2020) Novel coronavirus is putting the whole world on alert. J Hosp Infect 104(3):252-253

Kline K, Joseph R, Averill D Jr (1994) Feline infectious peritonitis with neurologic involvement: clinical and pathological findings in 24 cats. J Am Anim Hosp Assoc 30(2):111-118

Knobler S, Mahmoud A, Lemon S, Mack A, Sivitz L, Oberholtzer K (2004) In the Absence of SARS-CoV Transmission Worldwide: Guidance for Surveillance, Clinical and Laboratory Evaluation, and Reporting. Learning from SARS: Preparing for the Next Disease Outbreak: Workshop Summary, National Academies Press (US)

Körner RW, Majjouti M, Alcazar MAA, Mahabir E (2020) Of Mice and men: the coronavirus MHV and mouse models as a translational approach to understand SARS-CoV-2. Viruses 12(8):880

Koyuncu OO, Hogue IB, Enquist LW (2013) Virus infections in the nervous system. Cell Host Microbe 13(4):379-393

Kumar V (2020) Understanding the complexities of SARS-CoV2 infection and its immunology: A road to immune-based therapeutics. Int immunopharmacol 106980

Kuster GM, Pfister O, Burkard T, Zhou Q, Twerenbold R, Haaf P, Widmer AF, Osswald S (2020) SARS-CoV2: should inhibitors of the renin-angiotensin system be withdrawn in patients with COVID-19? Eur Heart J

Kwong KCNK, Mehta PR, Shukla G, Mehta AR (2020) COVID-19, SARS and MERS: A neurological perspective. J Clin Neurosci

Lau SK, Li KS, Tsang AK, Lam CS, Ahmed S, Chen H, Chan K-H, Woo PC, Yuen K-Y (2013) Genetic characterization of Betacoronavirus lineage $\mathrm{C}$ viruses in bats reveals marked sequence divergence in the spike protein of pipistrellus bat coronavirus HKU5 in Japanese pipistrelle: implications for the origin of the novel Middle East respiratory syndrome coronavirus. J Virol 87(15):8638-8650

Lavi E, Cong L (2020) Type I astrocytes and microglia induce a cytokine response in an encephalitic murine coronavirus infection. Exp Mol Pathol 115:104474

Lavi E, Weiss SR (1989) Coronaviruses. Springer, Clinical and Molecular Aspects of Neurotropic Virus Infection, pp 101-139

Lavi E, Weiss SR (2012) Department of Microbiology. Clinical and Molecular Aspects of Neurotropic Virus Infection 5:101

Leist SR, Cockrell AS (2020) Genetically engineering a susceptible mouse model for MERS-CoV-induced acute respiratory distress syndrome. Springer, MERS Coronavirus, pp 137-159

Li K, Wohlford-Lenane C, Perlman S, Zhao J, Jewell AK, Reznikov LR, Gibson-Corley KN, Meyerholz DK, McCray PB Jr (2016a) Middle East respiratory syndrome coronavirus causes multiple organ damage and lethal disease in mice transgenic for human dipeptidyl peptidase 4. J Infect Dis 213(5):712-722

Li W, Zhang C, Sui J, Kuhn JH, Moore MJ, Luo S, Wong SK, Huang IC, Xu K, Vasilieva N (2005) Receptor and viral determinants of SARS-coronavirus adaptation to human ACE2. EMBO J 24(8):1634-1643

Li YC, Bai WZ, Hashikawa T (2020) The neuroinvasive potential of SARS-CoV2 may play a role in the respiratory failure of COVID-19 patients. J Med Virol

Li Z, He W, Lan Y, Zhao K, Lv X, Lu H, Ding N, Zhang J, Shi J, Shan $\mathrm{C}(2016 \mathrm{~b})$ The evidence of porcine hemagglutinating encephalomyelitis virus induced nonsuppurative encephalitis as the cause of death in piglets. PeerJ 4:e2443

Lin B, Coleman JH, Peterson JN, Zunitch MJ, Jang W, Herrick DB, Schwob JE (2017) Injury induces endogenous reprogramming and dedifferentiation of neuronal progenitors to multipotency. Cell Stem Cell 21(6):761-774. e765

Lippi G, Sanchis-Gomar F, Henry BM (2020) Coronavirus disease 2019 (COVID-19): the portrait of a perfect storm. Ann Transl Med 8(7) 
Liu J, Zheng X, Tong Q, Li W, Wang B, Sutter K, Trilling M, Lu M, Dittmer U, Yang D (2020) Overlapping and discrete aspects of the pathology and pathogenesis of the emerging human pathogenic coronaviruses SARS-CoV, MERS-CoV, and 2019-nCoV. J Med Virol 92(5):491-494

Loeffelholz MJ, Tang Y-W (2020) Laboratory diagnosis of emerging human coronavirus infections-the state of the art. Emerging Microbes \& Infections 9(1):747-756

Lu H, Stratton CW, Tang YW (2020a) Outbreak of pneumonia of unknown etiology in Wuhan, China: the mystery and the miracle. J Med Virol 92(4):401-402

Lu R, Zhao X, Li J, Niu P, Yang B, Wu H, Wang W, Song H, Huang B, Zhu N (2020b) Genomic characterisation and epidemiology of 2019 novel coronavirus: implications for virus origins and receptor binding. The Lancet 395(10224):565-574

Lu S, Zhao Y, Yu W, Yang Y, Gao J, Wang J, Kuang D, Yang M, Yang $\mathrm{J}, \mathrm{Ma} \mathrm{C}$ (2020c) Comparison of SARS-CoV-2 infections among 3 species of non-human primates. bioRxiv

Lukassen S, Chua RL, Trefzer T, Kahn NC, Schneider MA, Muley T, Winter H, Meister M, Veith C, Boots AW (2020d) SARS-CoV-2 receptor ACE2 and TMPRSS2 are primarily expressed in bronchial transient secretory cells. EMBO J

Luo C, Qu H, Ma J, Wang J, Hu X, Li N, Shu D (2014) A genomewide association study identifies major loci affecting the immune response against infectious bronchitis virus in chicken. Infect Genet Evol 21:351-358

Machado C, Gutierrez JV (2020) Brainstem dysfunction in SARSCOV2 infection can be a potential cause of respiratory distress.

Malbon AJ, Michalopoulou E, Meli ML, Barker EN, Tasker S, Baptiste K, Kipar A (2020) Colony Stimulating Factors in Early Feline Infectious Peritonitis Virus Infection of Monocytes and in End Stage Feline Infectious Peritonitis; A Combined In Vivo and In Vitro Approach. Pathogens 9(11):893

Mao L, Wang M, Chen S, He Q, Chang J, Hong C, Zhou Y, Wang D, Miao X, Hu Y (2020) "Neurological manifestations of hospitalized patients with COVID-19 in Wuhan, China: a retrospective case series study."

Mariani CL (2020) Meningoencephalitis and Meningomyelitis. Clin Small Animal Intern Med 795-801

Martin J, Nathanson N (1979) Animal models of virus-induced demyelination. Progress in Neuropathology 4:27-50

Matías-Guiu J, Gomez-Pinedo U, Montero-Escribano P, GomezIglesias P, Porta-Etessam J, Matias-Guiu J (2020) Should we expect neurological symptoms in the SARS-CoV-2 epidemic? Neurología (English Edition)

Matsuda K, Park C, Sunden Y, Kimura T, Ochiai K, Kida H, Umemura $\mathrm{T}$ (2004) The vagus nerve is one route of transneural invasion for intranasally inoculated influenza a virus in mice. Vet Pathol 41(2):101-107

Mattern T, Scholz W, Feller A, Flad HD, Ulmer A (1991) Expression of CD26 (dipeptidyl peptidase IV) on resting and activated human T-lymphocytes. Scand J Immunol 33(6):737-748

McCray PB, Pewe L, Wohlford-Lenane C, Hickey M, Manzel L, Shi L, Netland J, Jia HP, Halabi C, Sigmund CD (2007) Lethal infection of K18-hACE2 mice infected with severe acute respiratory syndrome coronavirus. J Virol 81(2):813-821

Meekins DA, Morozov I, Trujillo JD, Gaudreault NN, Bold D, Carossino M, Artiaga BL, Indran SV, Kwon T, Balaraman V (2020) Susceptibility of swine cells and domestic pigs to SARS-CoV-2. Emerging Microbes \& Infections 9(1):2278-2288

Meinhardt J, Radke J, Dittmayer C, Mothes R, Franz J, Laue M, Schneider J, Brünink S, Hassan O, Stenzel W (2020) Olfactory transmucosal SARS-CoV-2 invasion as port of Central Nervous System entry in COVID-19 patients. BioRxiv

Moreno A, Lelli D, De Sabato L, Zaccaria G, Boni A, Sozzi E, Prosperi A, Lavazza A, Cella E, Castrucci MR (2017) Detection and full genome characterization of two beta $\mathrm{CoV}$ viruses related to Middle East respiratory syndrome from bats in Italy. Virology Journal 14(1):239

Munster V, Feldmann F, Williamson B, Van Doremalen N, PerezPerez L, Schultz J, Meade-White K, Okumura A, Callison J, Brumbaugh B (2020) Respiratory disease and virus shedding in rhesus macaques inoculated with SARS-CoV-2. BioRxiv

Munster VJ, de Wit E, Feldmann H (2013) Pneumonia from human coronavirus in a macaque model. New Eng J Med 368(16)

Murray RS, Cai G-Y, Hoel K, Zhang J-Y, Soike KF, Cabirac GF (1992) Coronavirus infects and causes demyelination in primate central nervous system. Virology 188(1):274-284

Nagashima K, Wege H, Meyermann R, Ter Meulen V (1979) Demyelinating encephalomyelitis induced by a long-term corona virus infection in rats. Acta Neuropathol 45(3):205-213

Najjar S, Najjar A, Chong DJ, Pramanik BK, Kirsch C, Kuzniecky RI, Pacia SV, Azhar S (2020) Central nervous system complications associated with SARS-CoV-2 infection: integrative concepts of pathophysiology and case reports. J Neuroinflammation 17(1):1-14

Nam H-S, Park JW, Ki M, Yeon M-Y, Kim J, Kim SW (2017) High fatality rates and associated factors in two hospital outbreaks of MERS in Daejeon, the Republic of Korea. Int J Infect Dis 58:37-42

Natoli S, Oliveira V, Calabresi P, Maia LF, Pisani A (2020) Does SARS-Cov-2 invade the brain? Translational lessons from animal models. Eur J Neurol

Netland J, Meyerholz DK, Moore S, Cassell M, Perlman S (2008) Severe acute respiratory syndrome coronavirus infection causes neuronal death in the absence of encephalitis in mice transgenic for human ACE2. J Virol 82(15):7264-7275

of the International, C. S. G (2020) The species Severe acute respiratory syndrome-related coronavirus: classifying 2019-nCoV and naming it SARS-CoV-2. Nat Microbiol 5(4):536

Oliveira AC, Richards EM, Karas MM, Pepine CJ, Raizada MK (2020) Would Repurposing Minocycline Alleviate Neurologic Manifestations of COVID-19? Front Neurosci 14

Organization, WHO (2003) Consensus document on the epidemiology of severe acute respiratory syndrome (SARS), World Health Organization

Organization, WHO (2019) Middle East respiratory syndrome coronavirus (MERS-CoV)

Organization, WHO (2020a) Coronavirus disease 2019 (COVID-19): situation report 73

Organization, WHO (2020b) Coronavirus disease 2019 (COVID-19): situation report 80

Organization, WHO (2020c) COVID-19 and the use of angiotensinconverting enzyme inhibitors and receptor blockers: scientific brief, 7 May 2020, World Health Organization

Organization, WHO (2020d) Laboratory testing for coronavirus disease 2019 (COVID-19) in suspected human cases: interim guidance, 2 March 2020, World Health Organization

Organization, WHO (2020e) Naming the coronavirus disease (COVID19) and the virus that causes it. https://www.who.int/emergencies/ diseases/novel-coronavirus-2019/technical-guidance/naming-thecoronavirus-disease-(covid-2019)-and-the-virus-that-causes-it.

Paniz-Mondolfi A, Bryce C, Grimes Z, Gordon RE, Reidy J, Lednicky J, Sordillo EM, Fowkes M (2020) Central nervous system involvement by severe acute respiratory syndrome coronavirus-2 (SARS-CoV-2). J Med Virol 92(7):699-702

Paybast S, Emami A, Koosha M, Baghalha F (2020) Novel coronavirus disease (COVID-19) and central nervous system complications: what neurologist need to know. Acta Neurol Taiwan 29(1):24-31

Perlman S, Zheng J, WONG LYR, Li K, Verma AK, Bezara MEO, Wohlford-Lenane C, Leidinger MR, Kundson MC, Meyerholz 
DK (2020) K18-hACE2 mice for studies of COVID-19 treatments and pathogenesis including anosmia. BioRxiv

Pfefferle S, Schöpf J, Kögl M, Friedel CC, Müller MA, Carbajo-Lozoya J, Stellberger T, von Dall'Armi E, Herzog P, Kallies S (2011) The SARS-coronavirus-host interactome: identification of cyclophilins as target for pan-coronavirus inhibitors. PLoS pathogens $7(10)$

Pickel K, Müller M, ter Meulen V (1981) Analysis of age-dependent resistance to murine coronavirus JHM infection in mice. Infect Immun 34(3):648-654

Podvin S, Wojnicz A, Hook V (2018) Human brain gene expression profiles of the cathepsin $\mathrm{V}$ and cathepsin $\mathrm{L}$ cysteine proteases, with the PC1/3 and PC2 serine proteases, involved in neuropeptide production. Heliyon 4(7)e00673

Raux H, Flamand A, Blondel D (2000) Interaction of the rabies virus $\mathrm{P}$ protein with the LC8 dynein light chain. J Virol 74(21):10212-10216

Reusken CB, Haagmans BL, Müller MA, Gutierrez C, Godeke G-J, Meyer B, Muth D, Raj VS, Smits-De Vries L, Corman VM (2013) Middle East respiratory syndrome coronavirus neutralising serum antibodies in dromedary camels: a comparative serological study. Lancet Infect Dis 13(10):859-866

Richard M, Knauf S, Lawrence P, Mather AE, Munster VJ, Müller MA, Smith D, Kuiken T (2017) Factors determining human-tohuman transmissibility of zoonotic pathogens via contact. Curr Opin Virol 22:7-12

Robin M (2017) Scientists trace 2002 Sars virus to colony of cavedwelling bats in China. The Guardian

Rohrer C, Suter P, Lutz H (1993) The diagnosis of feline infectious peritonitis (FIP): a retrospective and prospective study. Kleintierpraxis 38:379-389

Romoli M, Jelcic I, Bernard-Valnet R, García Azorín D, Mancinelli L, Akhvlediani T, Monaco S, Taba P, Sellner J, I. D. P. o. t. E. A. o. Neurology, (2020) A systematic review of neurological manifestations of SARS-CoV-2 infection: the devil is hidden in the details. Eur J Neurol 27(9):1712-1726

Rossen JW, Horzinek MC, Rottler PJ (1995) Coronavirus infection of polarized epithelial cells. Trends Microbiol 3(12):486-490

Rout SS, Singh M, Shindler KS, Sarma JD (2020) One proline deletion in the fusion peptide of neurotropic mouse hepatitis virus (MHV) restricts retrograde axonal transport and neurodegeneration. $\mathrm{J}$ Biol Chem 295(20):6926-6935

Sabir JS, Lam TT-Y, Ahmed MM, Li L, Shen Y, Abo-Aba SE, Qureshi MI, Abu-Zeid M, Zhang Y, Khiyami MA (2016) Co-circulation of three camel coronavirus species and recombination of MERSCoVs in Saudi Arabia. Science 351(6268):81-84

Santos I, Grosche dAVR, Bergamini FRG, Sabino-Silva R, Jardim ACG (2020) Antivirals against coronaviruses: candidate drugs for SARS-CoV-2 treatment? Front Microbiol 11:1818

Sarkar L, Putchala RK, Safiriyu AA, Das Sarma J (2020) Azadirachta indica A. Juss ameliorates mouse hepatitis virus-induced neuroinflammatory demyelination by modulating cell-to-cell fusion in an experimental animal model of multiple sclerosis. Front Cell Neurosci 14:116

Satarker S, Nampoothiri M (2020) Involvement of the nervous system in COVID-19: The bell should toll in the brain. Life Sci 118568

Schwender S, Imrich H, Dörries R (1991) The pathogenic role of virus-specific antibody-secreting cells in the central nervous system of rats with different susceptibility to coronavirusinduced demyelinating encephalitis. Immunology 74(3):533

Sharif-Yakan A, Kanj SS (2014) Emergence of MERS-CoV in the Middle East: origins, transmission, treatment, and perspectives. PLoS pathogens 10(12)

Singh AK, Bhushan B, Maurya A, Mishra G, Singh SK, Awasthi R (2020) Novel Coronavirus disease 2019 (COVID-19) and neurodegenerative disorders. Dermatol Ther e13591
Slauson DO, Finn JP (1972) Meningoencephalitis and panophthalmitis in feline infectious peritonitis. J Am Vet Med Assoc 160(5):729-734

Subbarao K, Roberts A (2006) Limitations of the available animal models. Trends Microbiol 7(14):299-303

Tabet E, Gelu-Simeon M, Genet V, Lamontagne L, Piquet-Pellorce C, Samson M (2018) Chlordecone potentiates auto-immune hepatitis and promotes brain entry of MHV3 during viral hepatitis in mouse models. Toxicol Lett 299:129-136

Timmann D, Cizinauskas S, Tomek A, Doherr M, Vandevelde M, Jaggy A (2008) Retrospective analysis of seizures associated with feline infectious peritonitis in cats. J Feline Med Surg 10(1):9-15

Toljan K (2020a) Letter to the editor regarding the viewpoint "evidence of the COVID-19 virus targeting the CNS: tissue distribution, host-virus interaction, and proposed neurotropic mechanism." ACS Chem Neurosci 11(8):1192-1194

Toljan K (2020b) Letter to the Editor Regarding the Viewpoint "Evidence of the COVID-19 Virus Targeting the CNS: Tissue Distribution, Host-Virus Interaction, and Proposed Neurotropic Mechanism." ACS Chem Neurosci 11(8):1192

Torre-Fuentes L, Moreno-Jiménez L, Pytel V, Matías-Guiu J, Gómez-Pinedo U, Matías-Guiu J (2020) Experimental models of demyelination and remyelination. Neurología (english Edition) 35(1):32-39

Tsai L, Hsieh S, Chang Y (2005) Neurological manifestations in severe acute respiratory syndrome. Acta Neurol Taiwan 14(3):113

Tseng C-TK, Huang C, Newman P, Wang N, Narayanan K, Watts DM, Makino S, Packard MM, Zaki SR, Chan T-S (2007) Severe acute respiratory syndrome coronavirus infection of mice transgenic for the human Angiotensin-converting enzyme 2 virus receptor. J Virol 81(3):1162-1173

UR A, Verma K (2020) Pulmonary Edema in COVID19-A Neural Hypothesis. ACS Chem Neurosci 11(14):2048-2050

Uversky VN, Elrashdy F, Aljadawi A, Ali SM, Khan RH, Redwan EM (2020). SARS-CoV-2 infection reaches the human nervous system: How?

Velavan TP, Meyer CG (2020) The COVID-19 epidemic. Tropical Med Int Health 25(3):278

Verdecchia P, Cavallini C, Spanevello A, Angeli F (2020) The pivotal link between ACE2 deficiency and SARS-CoV-2 infection. Eur J Inten Med

Vergara-Alert J, van den Brand JM, Widagdo W, Muñoz M (2017) Livestock susceptibility to infection with Middle East respiratory syndrome coronavirus. Emerg Infect Dis 23(2):232

Wang H, Hirabayashi M, Chambers JK, Uchida K, Nakayama H (2018) Immunohistochemical studies on meningoencephalitis in feline infectious peritonitis (FIP). J Vet Med Sci 18-0406

Wang K, Chen W, Zhou YS, Lian JQ, Zhang Z, Du P, Gong L, Zhang Y, Cui HY, Geng JJ (2020) SARS-CoV-2 invades host cells via a novel route: CD147-spike protein. BioRxiv

Wang L-F, Anderson DE (2019) Viruses in bats and potential spillover to animals and humans. Curr Opin Virol 34:79-89

Watanabe R, Eckstrand C, Liu H, Pedersen NC (2018) Characterization of peritoneal cells from cats with experimentally-induced feline infectious peritonitis (FIP) using RNA-seq. Vet Res 49(1):1-15

Wernery U, Corman VM, Wong EY, Tsang AK, Muth D, Lau SK, Khazanehdari K, Zirkel F, Ali M, Nagy P (2015) Acute Middle East respiratory syndrome coronavirus infection in livestock dromedaries, Dubai, 2014. Emerg Infect Dis 21(6):1019

Wertheim J, Chu D, Peiris J (2013) "Kosakovsky Pond SL, Poon LL. 2013". A case for the ancient origin of coronaviruses. J Virol 87:7039-7045

Wilson MP, Jack AS (2020) Coronavirus disease (COVID-19) in neurology and neurosurgery: A scoping review of the early literature. Clin Neurol Neurosurg 105866 
Wong AC, Li X, Lau SK, Woo PC (2019) Global epidemiology of bat coronaviruses. Viruses 11(2):174

Wong SK, Li W, Moore MJ, Choe H, Farzan M (2004) A 193amino acid fragment of the SARS coronavirus $\mathrm{S}$ protein efficiently binds angiotensin-converting enzyme 2 . J Biol Chem 279(5):3197-3201

Woo PC, Lau SK, Huang Y, Yuen K-Y (2009) Coronavirus diversity, phylogeny and interspecies jumping. Exp Biol Med 234(10):1117-1127

Woo PC, Lau SK, Lam CS, Lau CC, Tsang AK, Lau JH, Bai R, Teng JL, Tsang CC, Wang M (2012) Discovery of seven novel Mammalian and avian coronaviruses in the genus deltacoronavirus supports bat coronaviruses as the gene source of alphacoronavirus and betacoronavirus and avian coronaviruses as the gene source of gammacoronavirus and deltacoronavirus. J Virol 86(7):3995-4008

Woo PC, Wang M, Lau SK, Xu H, Poon RW, Guo R, Wong BH, Gao K, Tsoi H-W, Huang Y (2007) Comparative analysis of twelve genomes of three novel group $2 \mathrm{c}$ and group $2 \mathrm{~d}$ coronaviruses reveals unique group and subgroup features. J Virol 81(4):1574-1585

Wu D, Wu T, Liu Q, Yang Z (2020a) The SARS-CoV-2 outbreak: what we know. Int J Infect Dis

Wu Y, Xu X, Chen Z, Duan J, Hashimoto K, Yang L, Liu C, Yang C (2020b) Nervous system involvement after infection with COVID-19 and other coronaviruses. Brain Behav Immunity

Xia H, Lazartigues E (2008) Angiotensin-converting enzyme 2 in the brain: properties and future directions. J Neurochem 107(6): 1482-1494

Xiang P, Xu X, Gao L, Wang H, Xiong H, Li R (2020) First case of 2019 novel coronavirus disease with encephalitis. ChinaXiv 202003:00015

Xu J, Zhong S, Liu J, Li L, Li Y, Wu X, Li Z, Deng P, Zhang J, Zhong $\mathrm{N}$ (2005) Detection of severe acute respiratory syndrome coronavirus in the brain: potential role of the chemokine mig in pathogenesis. Clin Infect Dis 41(8):1089-1096
Yamazato M, Ferreira AJ, Yamazato Y, Diez-Freire C, Yuan L, Gillies R, Raizada MK (2011) Gene transfer of angiotensin-converting enzyme 2 in the nucleus tractus solitarius improves baroreceptor heart rate reflex in spontaneously hypertensive rats. J ReninAngiotensin-Aldosterone Syst 12(4):456-461

Yao Y, Bao L, Deng W, Xu L, Li F, Lv Q, Yu P, Chen T, Xu Y, Zhu H (2014) An animal model of MERS produced by infection of rhesus macaques with MERS coronavirus. J Infect Dis 209(2):236-242

Yashavantha Rao H, Jayabaskaran C (2020) The emergence of a novel coronavirus (SARS-CoV-2) disease and their neuroinvasive propensity may affect in COVID-19 patients. J Med Virol 92(7):786-790

Ye Z-W, Yuan S, Yuen K-S, Fung S-Y, Chan C-P, Jin D-Y (2020) Zoonotic origins of human coronaviruses. Int J Biol Sci 16(10): 1686

Yin Y, Wunderink RG (2018) MERS, SARS and other coronaviruses as causes of pneumonia. Respirology 23(2):130-137

Zaki AM, Van Boheemen S, Bestebroer TM, Osterhaus AD, Fouchier RA (2012) Isolation of a novel coronavirus from a man with pneumonia in Saudi Arabia. N Engl J Med 367(19):1814-1820

Zandifar S, Zandifar Z (2020) Acute Viral Encephalitis Associated with SARS-CoV-2. Ann Clin Case Rep 5:1845

Zhang YZ, Holmes EC (2020) A genomic perspective on the origin and emergence of SARS-CoV-2. Cell

Zhao J, Li K, Wohlford-Lenane C, Agnihothram SS, Fett C, Zhao J, Gale MJ, Baric RS, Enjuanes L, Gallagher T (2014) Rapid generation of a mouse model for Middle East respiratory syndrome. Proc Natl Acad Sci 111(13):4970-4975

Zumla A, Chan JF, Azhar EI, Hui DS, Yuen K-Y (2016) Coronaviruses-drug discovery and therapeutic options. Nat Rev Drug Discovery 15(5):327

Publisher's Note Springer Nature remains neutral with regard to jurisdictional claims in published maps and institutional affiliations. 